\title{
S-nitroso-N-acetylpenicillamine and nitroprusside induce apoptosis in a neuronal cell line by the production of different reactive molecules.
}

Citation for published version (APA):

Terwel, D., Nieland, L. J. W., Schutte, B., Reutelingsperger, C. P. M., Ramaekers, F. C. S., \& Steinbusch, H. W. M. (2000). S-nitroso-N-acetylpenicillamine and nitroprusside induce apoptosis in a neuronal cell line by the production of different reactive molecules. European Journal of Pharmacology, 400, 400-400. https://doi.org/10.1016/S0014-2999(00)00379-4

Document status and date:

Published: 01/01/2000

DOI:

10.1016/S0014-2999(00)00379-4

Document Version:

Publisher's PDF, also known as Version of record

Please check the document version of this publication:

- A submitted manuscript is the version of the article upon submission and before peer-review. There can be important differences between the submitted version and the official published version of record.

People interested in the research are advised to contact the author for the final version of the publication, or visit the DOI to the publisher's website.

- The final author version and the galley proof are versions of the publication after peer review.

- The final published version features the final layout of the paper including the volume, issue and page numbers.

Link to publication

\footnotetext{
General rights rights.

- You may freely distribute the URL identifying the publication in the public portal. please follow below link for the End User Agreement:

www.umlib.nl/taverne-license

Take down policy

If you believe that this document breaches copyright please contact us at:

repository@maastrichtuniversity.nl

providing details and we will investigate your claim.
}

Copyright and moral rights for the publications made accessible in the public portal are retained by the authors and/or other copyright owners and it is a condition of accessing publications that users recognise and abide by the legal requirements associated with these

- Users may download and print one copy of any publication from the public portal for the purpose of private study or research.

- You may not further distribute the material or use it for any profit-making activity or commercial gain

If the publication is distributed under the terms of Article $25 \mathrm{fa}$ of the Dutch Copyright Act, indicated by the "Taverne" license above, 


\title{
$S$-nitroso- $N$-acetylpenicillamine and nitroprusside induce apoptosis in a neuronal cell line by the production of different reactive molecules
}

\author{
Dick Terwel $^{\text {a, * }}$, Luc J.M. Nieland ${ }^{\text {b }}$, Bert Schutte ${ }^{\mathrm{b}}$, Chris P.M. Reutelingsperger ${ }^{\mathrm{c}}$, \\ Frans C.S. Ramaekers ${ }^{b}$, Harry W.M. Steinbusch ${ }^{\mathrm{a}}$ \\ a Department of Psychiatry and Neuropsychology, European Graduate School of Neuroscience (EURON), Maastricht University, P.O. Box 616, \\ 6200 MD Maastricht, Netherlands \\ ${ }^{\mathrm{b}}$ Department of Molecular Cell Biology and Genetics, Maastricht University, Maastricht, Netherlands \\ ${ }^{\mathrm{c}}$ Department of Biochemistry, Maastricht University, Maastricht, Netherlands
}

Received 28 January 2000; received in revised form 2 May 2000; accepted 19 May 2000

\begin{abstract}
CHP212 neuroblastoma cells were exposed to two different nitric oxide (NO) donors, $S$-nitroso- $N$-acetylpenicillamine and sodium nitroprusside. Apoptosis and necrosis were determined with flow cytometric analysis of annexin $\mathrm{V}$ binding and propodium iodide uptake. Both $S$-nitroso- $N$-acetylpenicillamine and sodium nitroprusside induced apoptosis, but with a different time dependency. Oxyhemoglobin (NO scavenger) attenuated the toxicity of $S$-nitroso- $N$-acetylpenicillamine, but had no effect on the toxicity of sodium nitroprusside. By contrast, deferoxamine (iron chelator) attenuated the toxicity of sodium nitroprusside, but had no effect on the toxicity of $S$-nitroso- $N$ acetylpenicillamine. Urate $\left(\mathrm{ONOO}^{-}\right.$scavenger) did not influence the toxicity of either $S$-nitroso- $N$-acetylpenicillamine or sodium nitroprusside, but protected from SIN-1 (3-morpholinosydnonimine, $\mathrm{ONOO}^{-}$donor). It was shown that both dithiothreitol and ascorbic acid affected the toxicity of $S$-nitroso- $N$-acetylpenicillamine and sodium nitroprusside in opposite ways. In the presence of dithiothreitol, superoxide dismutase and catalase decreased the toxicity of sodium nitroprusside. In the presence of cells, but not in their absence, $S$-nitroso- $N$-acetylpenicillamine decomposed with a half-life of about $4 \mathrm{~h}$ as assessed by the production of nitrite and absorbance reduction at $335 \mathrm{~nm}$. Sodium nitroprusside decomposed very slowly in the presence of cells as assessed by the production of ferrocyanide. It can be concluded that (1) slow and sustained release of NO from $S$-nitroso- $N$-acetylpenicillamine at the cell surface causes apoptosis in CHP212 cells, probably without the involvement of $\mathrm{ONOO}^{-}$, (2) sodium nitroprusside causes apoptosis by the production of $\mathrm{H}_{2} \mathrm{O}_{2}$ and/or iron, rather than NO, and probably has to be taken up by the cell for decomposition. (C) 2000 Elsevier Science B.V. All rights reserved.
\end{abstract}

Keywords: Nitric oxide (NO); Hydrogen peroxide; Apoptosis; Neuroblastoma; PC12; NO donor; Annexin V

\section{Introduction}

Nitric oxide (NO) is produced in the body by different isoforms of nitric oxide synthase (NOS) (Wang and Marsden, 1995). NO is involved in many disparate body functions, such as vasorelaxation, tumoricide and bacteriocide, and long term potentiation in the brain (for reviews see Moncada and Higgs, 1991; Dawson and Dawson, 1995).

\footnotetext{
" Corresponding author. Tel.: +31-43-3881023; fax: +31-43-3671096

E-mail address: d.terwel@np.unimaas.nl (D. Terwel).
}

The major target of NO is soluble guanylate cyclase (Katsuki et al., 1977), but many more molecules are modified by $\mathrm{NO}$ or reactive oxygen species derived from NO. Among these molecules are glyceraldehyde-3-phosphate dehydrogenase, aconitase and complexes of the mitochondrial electron transport chain containing an iron sulphur cluster (Drapier and Hibbs, 1988; Stadler et al., 1991; Castro et al., 1994; Mohr et al., 1994; Radi et al., 1994; Bolaños et al., 1995), as well as DNA (Wiseman and Halliwell, 1996). The ability of NO to disrupt the function or integrity of mitochondria and DNA has been held responsible for its bacteriocidal and tumoricidal action. NO 
has been shown to be involved in neuronal cell death following brain ischemia. However, results have not been unequivocal. This may be related to the different actions of $\mathrm{NO}$ in the brain and the experimental design (Iadecola, 1997). NO has also been shown to be toxic to primary cultures of brain cortex cells (Dawson et al., 1991; Lipton et al., 1993). However, Wink et al. (1993) obtained evidence for a protective role of NO in primary cultures of mesencephalic brain cells.

Several studies have addressed the question whether cell death induced by NO is of an apoptotic or necrotic nature. Chondrocytes, thymocytes, pancreatic beta-cells and macrophages have been shown to become apoptotic upon exposure to NO (Blanco et al., 1995; Fehsel et al., 1995; Kaneto et al., 1995; Messmer et al., 1995). On the other hand, oligodendrocytes have been shown to become necrotic when exposed to NO (Mitrovic et al., 1995). Recently it has been reported that $S$-nitrocysteine causes injury with apoptotic features in primary cultured neurons (Bonfoco et al., 1995). However, only nuclear condensation, but not fragmentation, and some internucleosomal degradation of DNA were evident.

It is not clear whether $\mathrm{NO}$ itself or $\mathrm{ONOO}^{-}$, the reaction product of $\mathrm{NO}$ and $\mathrm{O}_{2}^{--}$, is the toxic agent that causes cell death upon exposure to NO. It has been shown that both exposure of $\mathrm{NO}$ and $\mathrm{ONOO}^{-}$induces cell death in a number of cell types (e.g. Messmer et al., 1995; Lipton et al., 1993). Cu, Zn superoxide dismutase-deficient PC12 cells have been shown to be more sensitive to NO and toxicity in these cells was blocked by NOS inhibitors (Troy et al., 1996), which was taken as evidence for the involvement of $\mathrm{ONOO}^{-}$. Several studies seem to indicate that the $\mathrm{NO}^{+}$donor sodium nitroprusside induces higher percentages of apoptotic cells than $\mathrm{NO}^{-}$donors, at least in some cell types (e.g. Messmer et al., 1995; Khan et al., 1997).

The aim of the present study was to gain more insight into cell death induced in a neuronal cell line (CHP212) by two of the most frequently used NO donors ( $S$-nitroso- $N$ acetylpenicillamine and sodium nitroprusside), with respect to type of cell death, time course of cell death, site of decomposition of the $\mathrm{NO}$ donors and free radicals involved in cell death. Apoptosis or necrosis in CHP212 cells was assessed by flow cytometric and microscopic analysis of annexin V-fluorescein isothiocyanate (FITC) binding and propidium iodide uptake (Van Engeland et al., 1996). Dose-response and time course studies indicate profound differences in the action of $S$-nitroso- $N$-acetylpenicillamine and sodium nitroprusside on the induction of apoptosis. The effects of $S$-nitroso- $N$-acetylpenicillamine and sodium nitroprusside on cell death were modified in different ways by hemoglobin, reductants, superoxide dismutase, catalase and deferoxamine. The effects of the NO donors on cell death were compared to those of olomoucine, a general inducer of apoptosis (Van Engeland et al., 1996; Schutte et al., 1997).

\section{Materials and methods}

\subsection{Chemicals}

Annexin V-FITC (APOPTEST-FITC) was obtained from NeXins Research (Rotterdam, The Netherlands). Olomoucine was a kind gift by Dr. L. Meyer (Station Biologique, CNRS, Roscoff, France). Sodium nitroprusside and $\mathrm{H}_{2} \mathrm{O}_{2}$ were purchased from Merck (Darmstadt, FRG). $S$-nitroso- $N$-acetylpenicillamine and 1-methyl-4-phenylpyridinium ion $\left(\mathrm{MPP}^{+}\right)$were obtained from RBI (Natick, US), lactate dehydrogenase and nitrate reductase from Boehringer (Mannheim, FRG), catalase, superoxide dismutase, methemoglobin and 3-morpholinosydnonimine (SIN-1) from Sigma (St. Louis, US), deferoxamine from Ciba-Geigy (Basel, Switzerland), 3-(4,5-dimethylthiazol2-yl)-2,5-diphenyltetrazolium bromide (MTT) from ICN (Aurora, US). Other substances were from different suppliers and were all of p.a. grade. Oxyhemoglobin was prepared from methemoglobin as described by Murphy and Noack (1994).

\subsection{Cell culture}

CHP212 cells were grown in Costar 75-ml flasks in 5 $\mathrm{ml}$ Dulbecco's modified Eagles medium (DMEM, Gibco, Paisly, UK) supplemented with $10 \%$ newborn calfserum (Gibco), $1 \mathrm{mM}$ L-glutamine and $0.1 \%$ gentamycine. The medium was refreshed every 2 days and the cells were passaged when confluent. Twenty-four to fourty-eight hours before experimentation cells were transferred to 12-well-plates (Costar, Badhoevedorp, The Netherlands). PC12 cells were grown in Costar 75-ml flasks in $5 \mathrm{ml}$ DMEM/F12 (Gibco) medium supplemented with $10 \%$ horse serum (Gibco), 10\% fetal calf serum (Gibco), $1 \mathrm{mM}$ L-glutamine and $0.1 \%$ gentamycine. Twenty-four hours before experimentation cells were transferred to 12-wellplates that were coated with poly-L-lysine.

\subsection{Determination of apoptosis and necrosis}

Apoptosis was detected by making use of the property that apoptotic cells expose phosphatidylserine at their outer membrane leaflet, while remaining inaccessible to propidium iodide. Surface exposure of phosphatidylserine was visualized using annexin V-FITC (Van Engeland et al., 1996).

\subsubsection{Microscopic analysis of annexin V-FITC binding and propidium iodide uptake}

Cells were exposed to FITC-conjugated annexin V (0.25 $\mu \mathrm{g} / \mathrm{ml})$ and propidium iodide $(3 \mu \mathrm{g} / \mathrm{ml}) /$ RNAse (30 $\mu \mathrm{g} / \mathrm{ml}$ ) for $10 \mathrm{~min}$. The cells were examined using a Zeiss inverted microscope equipped with a phase contrast filter, appropriate bandpass filters and a mercury lamp. 


\subsubsection{Flow cytometric analysis of annexin V-FITC binding and propidium iodide uptake}

Cells were prepared and flow cytometric analysis was carried out as previously described by Van Engeland et al. (1996). Using this procedure four populations of cells can be distinguished in a bivariate annexin V-FITC binding/ propidium iodide uptake analysis, i.e., viable (R2), damaged during the harvesting procedure (R3), apoptotic (R4) and primary necrotic or secondary necrotic (R5), a feature of late apoptosis. For simplicity the term necrosis is used here to indicate both primary necrosis and secondary necrosis unless otherwise indicated. The percentage of apoptotic or necrotic cells is corrected for spontaneous apoptosis and necrosis to give the true percentage apoptotic or necrotic cells due to treatment.

\subsubsection{Determination of cell viability}

In one experiment cell viability was determined as the ability to reduce MTT. Cells were incubated with 0.5 $\mathrm{mg} / \mathrm{ml}$ MTT for $2 \mathrm{~h}$. Subsequently, medium was aspirated and the precipitated formazan was dissolved in dimethylsulfoxide. Absorbance was read at $554 \mathrm{~nm}$.

\subsection{Decomposition of S-nitroso- $N$-acetylpenicillamine and sodium nitroprusside}

\subsubsection{Spectrophotometric determination}

Decomposition of $S$-nitroso- $N$-acetylpenicillamine in the incubation medium was measured spectrophotometrically at $335 \mathrm{~nm}$. Decomposition of sodium nitroprusside in the incubation medium was measured indirectly as the release of $\mathrm{Fe}^{2+}$ that can be complexed to 1,10-phenanthroline. This complex has a red color with a maximal absorbance at $511 \mathrm{~nm}$. $\mathrm{FeSO}_{4}$ freshly dissolved in bidistilled water was used as a standard.

\subsubsection{Production of $\mathrm{NO}_{2}^{-}$and $\mathrm{NO}_{x}^{-}$}

Production of $\mathrm{NO}_{2}^{-}$, a decomposition product of $\mathrm{NO}$, in cell culture medium in the presence of cells was measured using the Griess reagent (Grisham et al., 1996). For the determination of $\mathrm{NO}_{x}^{-}, \mathrm{NO}_{3}^{-}$was converted to $\mathrm{NO}_{2}^{-}$using nitrate reductase with $\mathrm{NADPH}$ as a cofactor. Unreacted NADPH was converted to NADP ${ }^{+}$in the lactate dehydrogenase-catalyzed reaction (Grisham et al., 1996).

\subsubsection{Production of ferrocyanide from sodium nitroprus- side}

The production of ferrocyanide from sodium nitroprusside was determined as described by Hartly et al. (1985). Briefly, to $100-\mu 1$ samples of culture medium $0.9 \mathrm{ml}$ of $1 \% \mathrm{H}_{2} \mathrm{SO}_{4} / 1 \% \mathrm{FeSO}_{4}$ was added. Absorbance was read immediately at $750 \mathrm{~nm}$. Decomposition of sodium nitroprusside was calculated from the production of ferrocyanide according to the stochiometry for the decomposition of sodium nitroprusside. Release of three molecules NO from sodium nitroprusside is accompanied by the production of two molecules of ferrocyanide (e.g. Bates et al., 1991; Rao et al., 1991).

\subsection{Statistics}

Data were subjected to a one-way Analysis of Variance with treatment as the independent variable. Treatment effects between the experimental groups were evaluated in more detail by using the Student-Newman-Keuls test.

\section{Results}

\subsection{Microscopic analysis}

In order to investigate the mode of cell death induced by NO, CHP212 cells were exposed to $S$-nitroso- $N$ acetylpenicillamine and sodium nitroprusside for $4 \mathrm{~h}$ and $16 \mathrm{~h}$. For comparison cells were also treated with olomoucine for $4 \mathrm{~h}$ and $16 \mathrm{~h}$, and $\mathrm{H}_{2} \mathrm{O}_{2}$ for $16 \mathrm{~h}$. Annexin V-FITC binding and propidium iodide uptake by the cells were studied microscopically. The cells were also observed with phase contrast. Characteristic examples of our observations are shown in Fig. 1. Part of the cells exposed to $0.25 \mathrm{mM} S$-nitroso- $N$-acetylpenicillamine or $0.2 \mathrm{mM}$ olomoucine for $4 \mathrm{~h}$ showed affinity for annexin V-FITC, but excluded propidium iodide (Fig. 1A,B). At higher concentrations of $S$-nitroso- $N$-acetylpenicillamine ( 2 or $4 \mathrm{mM}$ ) for $4 \mathrm{~h}$, the cells became primary necrotic as indicated by a diffuse nuclear morphology, nonadherence, swollen appearance and the absence of budding. A large fraction of the cells exposed to $0.25 \mathrm{mM} S$-nitroso- $N$-acetylpenicillamine or $0.1 \mathrm{mM}$ olomoucine had taken up propidium iodide after $16 \mathrm{~h}$. The chromatin of this fraction of cells was condensed and fragmented in a fashion typical of late stage apoptosis. During transition from apoptosis to secondary necrosis, cells and apoptotic bodies started to swell (compare Figs. 1A,G and H). Cells exposed to 1 or $2 \mathrm{mM}$ sodium nitroprusside for $4 \mathrm{~h}$ showed no signs of necrosis or apoptosis. Many cells exposed to sodium nitroprusside for $16 \mathrm{~h}$ were apoptotic or secondary necrotic, the former fraction only bound annexin V-FITC and the latter fraction was permeable to propidium iodide as well (Fig. 1C,D). Similar results were obtained with cells incubated with 0.25 or $0.5 \mathrm{mM} \mathrm{H}_{2} \mathrm{O}_{2}$. However, cells exposed to $1 \mathrm{mM}$ $\mathrm{H}_{2} \mathrm{O}_{2}$ became primary necrotic (Fig. 1E,F). Although secondary necrotic cells were swollen and rounded they still could be distinguished from primary necrotic cells by their fragmented nuclei and smaller size (compare Fig. 1A, F, G and $\mathrm{H})$.

\subsection{Flow cytometric analysis}

In order to study the mode of cell death by the agents used in more detail, dose-response and time dependency studies were performed using flow cytometry. 

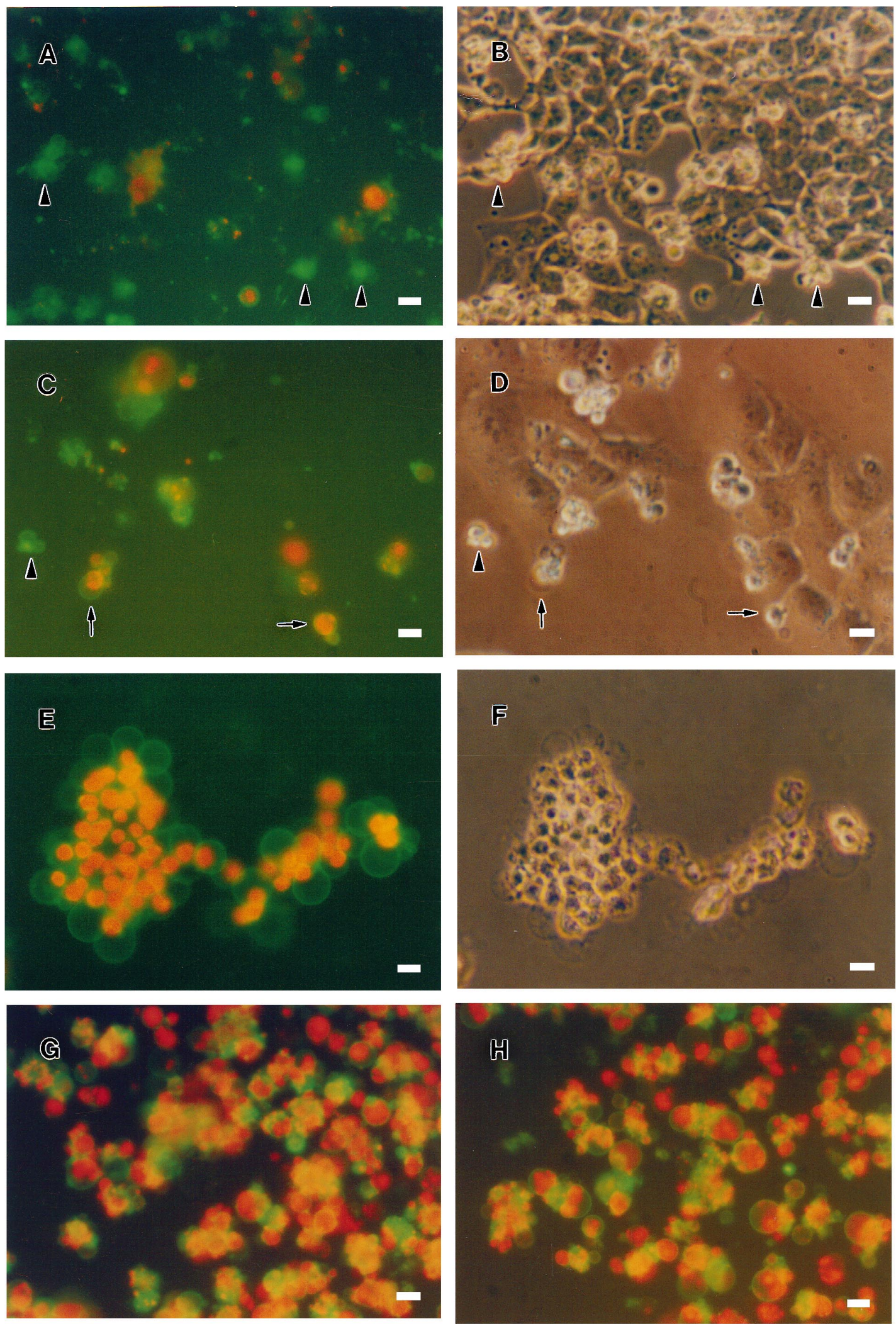

Fig. 1. Microscopic detection of apoptosis using annexin V-FITC and propidium iodide. Fluorescence photomicrographs of annexin V-FITC- and propidium iodide-labeled CHP212 cells exposed to $0.2 \mathrm{mM}$ olomoucine for $4 \mathrm{~h}(\mathrm{~A}), 1 \mathrm{mM}$ sodium nitroprusside for $16 \mathrm{~h}(\mathrm{C}), 1 \mathrm{mM} \mathrm{H} \mathrm{O}_{2}$ for $16 \mathrm{~h}$ (E), $0.1 \mathrm{mM}$ olomoucine for $16 \mathrm{~h}(\mathrm{G})$ or $0.25 \mathrm{mM} S$-nitroso- $N$-acetylpenicillamine for $16 \mathrm{~h}(\mathrm{H})$. (B, D, F) Phase contrast photomicrographs matching with fluorescence photomicrographs (A, C, E). Arrow heads indicate early apoptotic cells. Arrows indicate secondary necrotic cells. Bar $=12 \mu \mathrm{m}$. 
3.2.1. Dose-response relation of the effect of S-nitroso- $N$ acetylpenicillamine, sodium nitroprusside, $\mathrm{H}_{2} \mathrm{O}_{2}$ and olomoucine on the fraction of apoptotic and necrotic cells

Fig. 2 shows fractions of apoptotic and necrotic CHP212 cells caused by exposure to different concentrations of $S$-nitroso- $N$-acetylpenicillamine, sodium nitroprusside, $\mathrm{H}_{2} \mathrm{O}_{2}$ and olomoucine for $4,16,16$ and $4 \mathrm{~h}$, respectively. Similar to the effect of olomoucine (Fig. 2D), the fraction of apoptotic cells increased with increasing concentrations of sodium nitroprusside (Fig. 2B). Even at high concentrations of sodium nitroprusside the fraction of apoptotic cells was larger than the fraction of necrotic cells (see also Section 3.1 and below). In contrast, an increasing fraction of necrotic cells was observed with increasing concentrations of $S$-nitroso- $N$-acetylpenicillamine, whereas the distribution of the apoptotic fraction was biphasic (Fig. 2A, see also Section 3.1). This fraction was maximal at 0.25 $\mathrm{mM} S$-nitroso- $N$-acetylpenicillamine and decreased at higher concentrations of $S$-nitroso- $N$-acetylpenicillamine (2-4 mM). This decrease in the fraction of apoptotic cells was paralleled by an increase in the fraction of necrotic cells. Similar effects were observed for $\mathrm{H}_{2} \mathrm{O}_{2}$ (Fig. 2C). High concentrations of $\mathrm{H}_{2} \mathrm{O}_{2}$ resulted primarily in large fractions of necrotic cells (see also Section 3.1 and below).

It should be noted that the flow cytometric analysis does not discriminate between different forms of necrosis, that is necrosis as a primary event or necrosis as a late stage of apoptosis. However, as observed by microscopic observation (see Section 3.1) necrosis occurred mainly as late stage apoptosis with low concentrations of $S$-nitroso$\mathrm{N}$-acetylpenicillamine $(0.125-1 \mathrm{mM})$, or $\mathrm{H}_{2} \mathrm{O}_{2}(0.25-0.5$ $\mathrm{mM})$ and with all concentrations of sodium nitroprusside or olomoucine tested. These observations were of a qualitative nature. To obtain quantitative information on the annexin V-FITC/propidium iodide labeled fraction with regard to the type of cell death, cells were scored for nuclear morphology for some pertinent conditions. A minimum of 400 cells were scored per condition on two to three photomicrographs taken randomly at $400 \times$ magnification. At $2 \mathrm{mM}$ sodium nitroprusside, $0.25 \mathrm{mM} S$-nitroso$N$-acetylpenicillamine, $0.25 \mathrm{mM} \mathrm{H}_{2} \mathrm{O}_{2}$ or $0.2 \mathrm{mM}$ olomoucine for $16 \mathrm{~h}$, no primary necrotic cells were observed. At $0.5 \mathrm{mM} \mathrm{H}_{2} \mathrm{O}_{2}, 26.4 \pm 0.7 \%$ (mean \pm S.E.M., $n=3$ ) of the dead cells was primary necrotic, whereas the remainder was secondary necrotic. At $1 \mathrm{mM} \mathrm{H} \mathrm{H}_{2} \mathrm{O}_{2}, 88.3 \pm 1.0 \%$ (mean \pm S.E.M., $n=3$ ) of the dead cells was primary necrotic.

3.2.2. Time course of apoptosis induced by S-nitroso- $N$ acetylpenicillamine, sodium nitroprusside, $\mathrm{H}_{2} \mathrm{O}_{2}$ and olomoucine

In order to measure the kinetics of cell death by NO, CHP212 cells were incubated for various periods of time
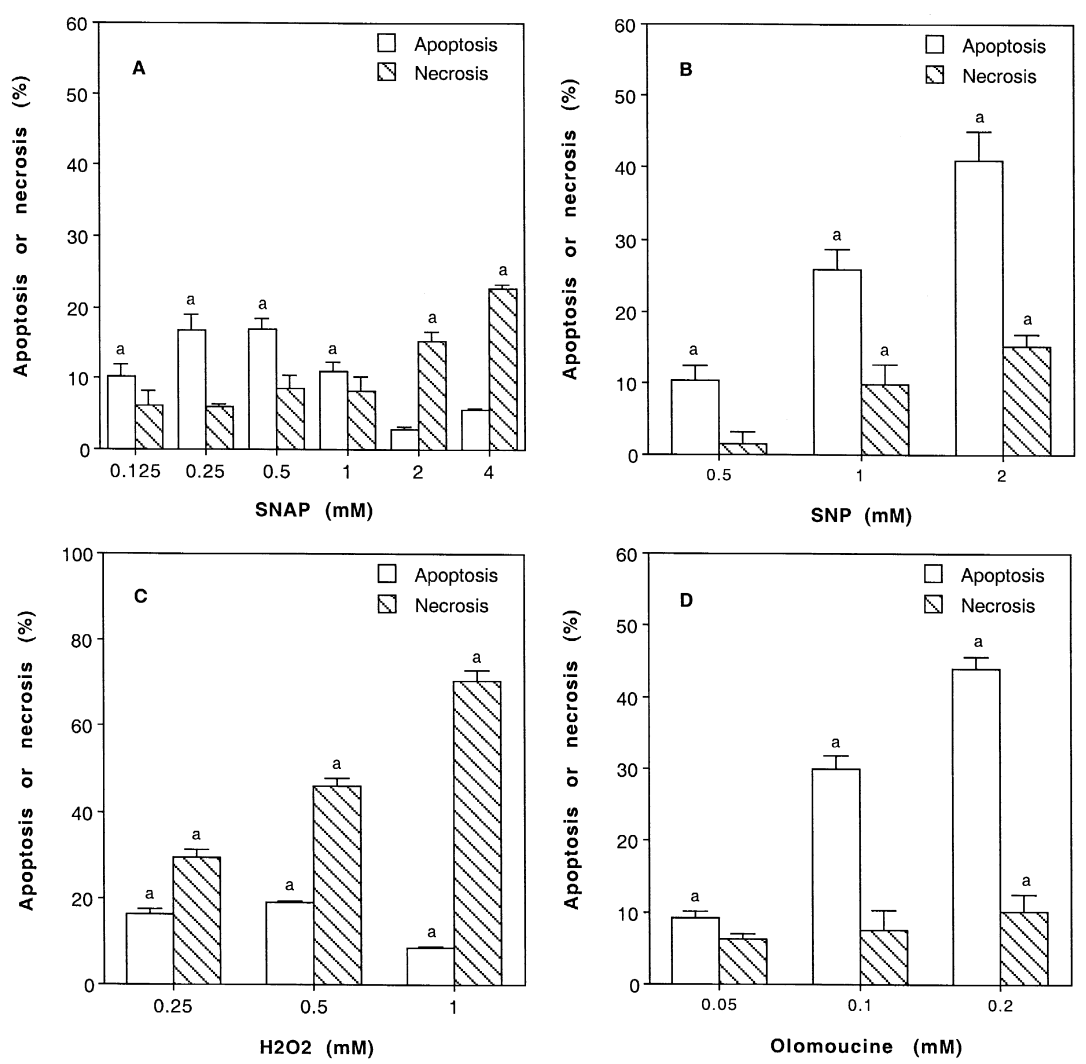

Fig. 2. Dose dependent effect of $S$-nitroso- $N$-acetylpenicillamine, sodium nitroprusside, $\mathrm{H}_{2} \mathrm{O}_{2}$ and olomoucine on apoptosis and necrosis in CHP212 cells. Cells were exposed to $S$-nitroso- $N$-acetylpenicillamine and olomoucine for $4 \mathrm{~h}$ and to sodium nitroprusside and $\mathrm{H}_{2} \mathrm{O}_{2}$ for $16 \mathrm{~h}$. Data represent means \pm S.E.M. of triplicate determinations. ${ }^{a}$ Indicates a significant difference from control $(P<0.05)$. 

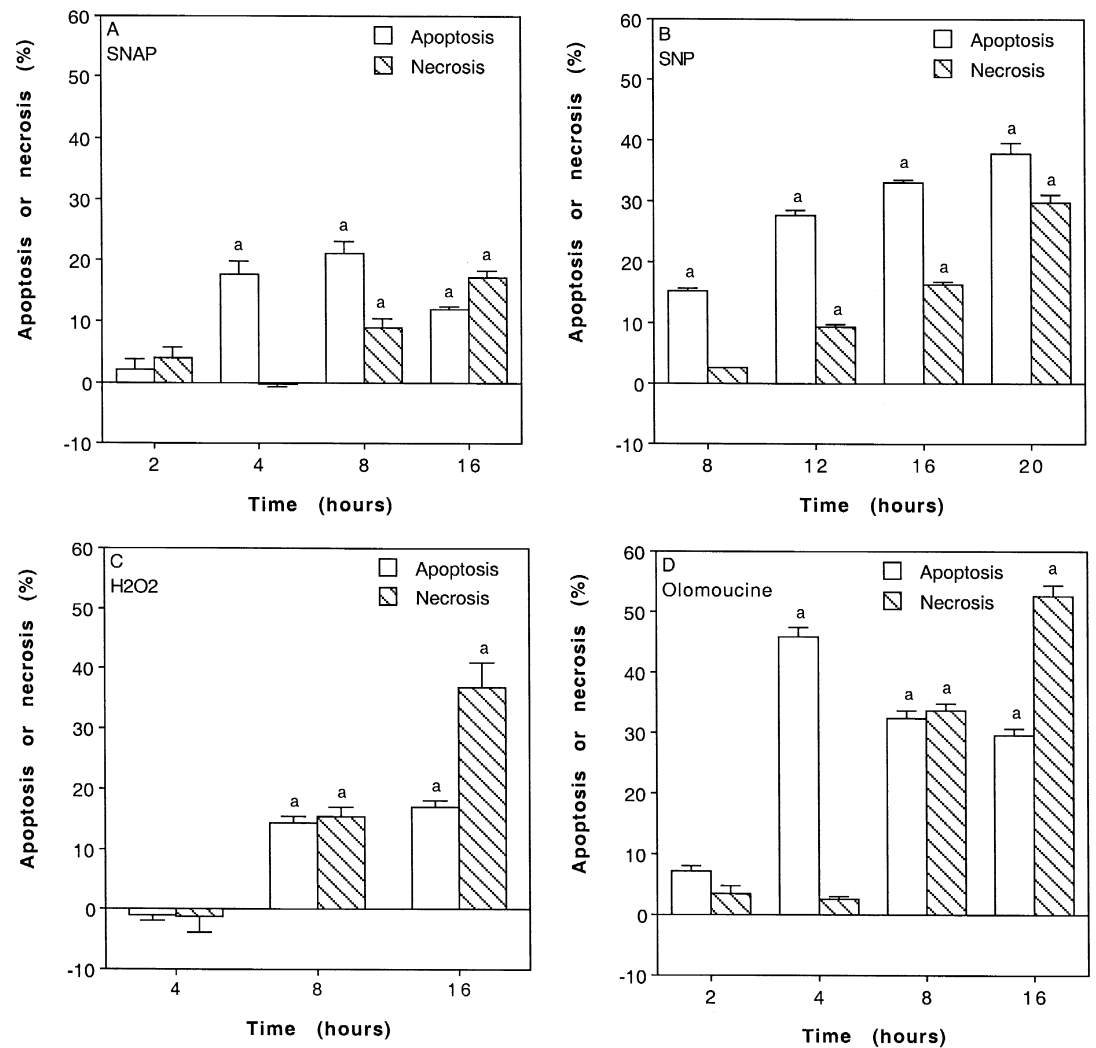

Fig. 3. Time dependent effect of $0.5 \mathrm{mM} S$-nitroso- $N$-acetylpenicillamine, $2 \mathrm{mM}$ sodium nitroprusside, $0.5 \mathrm{mM} \mathrm{H}_{2} \mathrm{O}_{2}$ and $0.2 \mathrm{mM}$ olomoucine on apoptosis and necrosis in CHP212 cells. Data represent means \pm S.E.M. of triplicate determinations. ${ }^{a}$ Indicates a significant difference from control $(P<0.05)$.

in the presence of $2 \mathrm{mM}$ sodium nitroprusside or $0.25 \mathrm{mM}$ $S$-nitroso- $N$-acetylpenicillamine. Results were compared with apoptosis induced by olomoucine and $\mathrm{H}_{2} \mathrm{O}_{2}$ at concentrations of 0.2 and $0.5 \mathrm{mM}$, respectively. Apoptosis was induced most rapidly in cells exposed to olomoucine, reaching maximal levels of $45 \%$ within $4 \mathrm{~h}$ (Fig. 3D). Thereafter the apoptotic fraction declined in favor of an increase in the fraction of necrotic cells, due to loss of membrane integrity as was observed microscopically. A somewhat slower time course of apoptosis was followed by cells exposed to $S$-nitroso- $N$-acetylpenicillamine (Fig. $3 \mathrm{~A})$. The maximum number of apoptotic cells was found after $8 \mathrm{~h}$ of incubation. Thereafter, the number of necrotic cells increased, again at the expense of the number of apoptotic cells. Sodium nitroprusside induced apoptosis with the slowest time course (Fig. 3B). Apoptotic cells were present from $8 \mathrm{~h}$ onwards, necrotic cells were only present from $12 \mathrm{~h}$ onwards. In contrast, $\mathrm{H}_{2} \mathrm{O}_{2}$ gave rise to an increase in numbers of apoptotic and necrotic cells at early stages and the numbers of the latter kept increasing until $16 \mathrm{~h}$ of incubation (Fig. 3C).

\subsection{Effect of reductants on cell death induced by sodium nitroprusside or S-nitroso- $\mathrm{N}$-acetylpenicillamine}

Sodium nitroprusside requires reduction to release NO. Lipton et al. (1993) used ascorbate as reducing agent to enhance the decomposition of sodium nitroprusside. It is unlikely that $S$-nitrosothiols release NO through spontaneous homolytic cleavage, rather, release may be driven by endogenous reductants such as ascorbate (e.g. Arnelle and Stamler, 1995). For these reasons the effect of reductants on cell death induced by sodium nitroprusside and $S$ nitroso- $N$-acetylpenicillamine-induced were studied. The presence of ascorbate $(0.5 \mathrm{mM})$ in the incubation medium

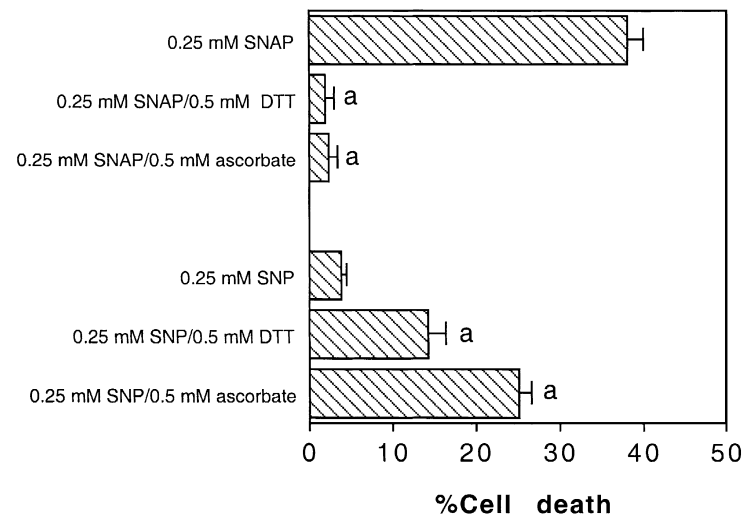

Fig. 4. Effect of reductants on cell death mediated by sodium nitroprusside or $S$-nitroso- $N$-acetylpenillamine. CHP212 cells were exposed to the above substances for a period of $16 \mathrm{~h}$. Cell death is the sum of apoptosis and necrosis. Data represent means \pm S.E.M. of triplicate determinations. ${ }^{a}$ Indicates a significant difference from the condition without reductant $(P<0.05)$. 


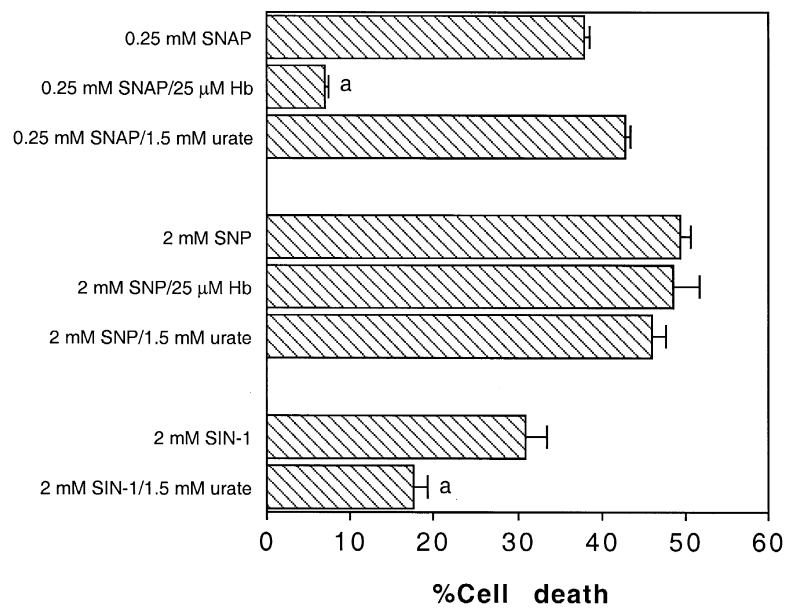

Fig. 5. Effect of oxyhemoglobin $(\mathrm{Hb})$ and urate on cell death mediated by sodium nitroprusside (SNP) or $S$-nitroso- $N$-acetylpenicillamine (SNAP). Cells were preincubated with urate for $6 \mathrm{~h}$ and exposed to $S$-nitroso- $N$ acetylpenicillamine or sodium nitroprusside (SNP) for $16 \mathrm{~h} .{ }^{\mathrm{a}}$ Indicates a significant difference from the condition without oxyhemoglobin or urate $(P<0.05)$. See legend of Fig. 4 for further details.

strongly increased the effect of sodium nitroprusside $(0.25$ $\mathrm{mM}$ ) on the number of dead cells (Fig. 4). A similar result was obtained when dithiothreitol $(0.5 \mathrm{mM})$ was added to the incubation medium (Fig. 4). By contrast, ascorbate and dithiothreitol strongly protected against the effect of $S$ nitroso- $N$-acetylpenicillamine $(0.25 \mathrm{mM})$ on the number of dead cells. The number of dead cells in the presence of ascorbate and dithiothreitol, did not exceed that in control cultures (data not shown).

\subsection{Effect of manipulation of reactive oxygen species on} cell death induced by $\mathrm{S}$-nitroso- $\mathrm{N}$-acetylpenicillamine, sodium nitroprusside or SIN-1

\subsubsection{Effect of $\mathrm{NO}-$ and $\mathrm{ONOO}^{-}$scavenger on cell} death induced by $S$-nitroso- $N$-acetylpenicillamine or sodium nitroprusside

Oxyhemoglobin, an extracellular NO scavenger, almost completely abrogated the cell death induced by $S$-nitroso$\mathrm{N}$-acetylpenicillamine, but was ineffective with respect to cell death induced by sodium nitroprusside (Fig. 5). Urate, a cell permeable $\mathrm{ONOO}^{-}$scavenger did not affect cell death either induced by $S$-nitroso- $N$-acetylpenicillamine or sodium nitroprusside. It should be noted that ascorbate and dithiothreitol, which are also $\mathrm{ONOO}^{-}$scavengers, did prevent cell death induced by $S$-nitroso- $N$-acetylpenicillamine. The number of dead cells in the presence of oxyhemoglobin and urate did not exceed that in control cultures (data not shown). To assess the efficacy of urate as a $\mathrm{ONOO}^{-}$scavenger, the ability of urate to protect CHP212 cells against the $\mathrm{NO} / \mathrm{O}_{2}^{--}$donor $\mathrm{SIN}-1$ was tested. Urate was able to protect $\mathrm{CHP} 212$ cells against SIN-1 (Fig. 5).
3.4.2. Effect of superoxide dismutase and catalase on cell death induced by $S$-nitroso- $N$-acetylpenicillamine, sodium nitroprusside or SIN-1

The differential effect of reductants on apoptosis mediated by sodium nitroprusside or mediated by $S$-nitroso- $N$ acetylpenicillamine points to the involvement of different reactive oxygen species, such as $\mathrm{NO}, \mathrm{ONOO}^{-}, \mathrm{O}_{2}^{--}$and $\mathrm{H}_{2} \mathrm{O}_{2}$. To scavenge $\mathrm{O}_{2}^{--}$and $\mathrm{H}_{2} \mathrm{O}_{2}$, superoxide dismutase and catalase were used. Superoxide dismutase and catalase did not affect the level of cell death induced by $S$-nitroso$\mathrm{N}$-acetylpenicillamine (Fig. 6). Superoxide dismutase increased the level of cell death induced by sodium nitroprusside alone (Fig. 6). This was reduced again to the level induced by sodium nitroprusside alone when catalase was also present (Fig. 6). By contrast, superoxide dismutase somewhat reduced the effect of sodium nitroprusside in the presence of dithiothreitol, whereas catalase prevented the effect of sodium nitroprusside on the number of dead cells in the presence of dithiothreitol (Fig. 6).

To compare the toxicity of $\mathrm{ONOO}^{-}$and NO, CHP2 12 cells were exposed to SIN-1 in the presence and absence of superoxide dismutase and catalase. SIN-1/superoxide dismutase/catalase was more toxic than SIN-1 indicating that $\mathrm{NO}$ was more toxic than $\mathrm{ONOO}^{-}$to $\mathrm{CHP} 212$ cells (Fig. 6). The presence of only superoxide dismutase increased the toxicity of SIN-1, probably due to the increased production of $\mathrm{H}_{2} \mathrm{O}_{2}$ (Fig. 6).

\subsubsection{Effect of $\mathrm{MPP}^{+}$on cell death induced by S-nitroso- $\mathrm{N}$-acetylpenicillamine}

A possible involvement of $\mathrm{ONOO}^{-}$in cell death induced by $S$-nitroso- $N$-acetylpenicillamine was further in-

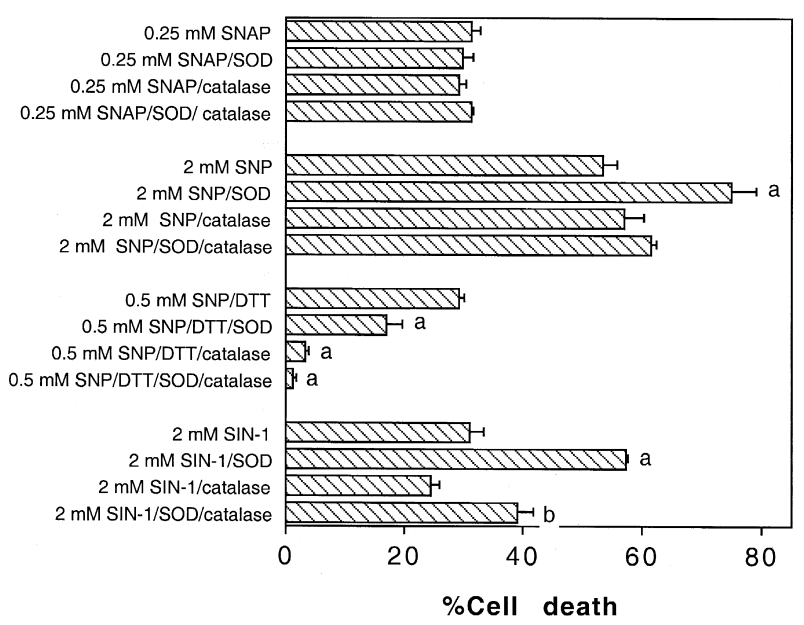

Fig. 6. The effect of superoxide dismutase (SOD) and catalase on cell death mediated by $S$-nitroso- $N$-acetylpenicillamine (SNAP), sodium nitroprusside (SNP), sodium nitroprusside/DTT (dithiothreitol) or SIN-1. Concentrations superoxide dismutase, catalase and dithiothreitol were 750 $\mathrm{U} / \mathrm{ml}, 6000 \mathrm{U} / \mathrm{ml}$ and $0.5 \mathrm{mM}$, respectively. ${ }^{\mathrm{a}}$ Indicates a significant difference from the condition without superoxide dismutase and/or catalase $(P<0.05)$. ${ }^{\mathrm{b}}$ Indicates a significant difference from the condition with SIN-1/catalase $(P<0.05)$. See legend of Fig. 4 for further details. 
vestigated by increasing the intracellular production of $\mathrm{O}_{2}^{--}$. To this end cells were exposed to $\mathrm{MPP}^{+}$, which has been shown to increase $\mathrm{O}_{2}^{--}$production (e.g. Packer et al., 1996; Sawada et al., 1996). Cells were preincubated with $\mathrm{MPP}^{+}$for $24 \mathrm{~h}$ before the addition of $S$-nitroso- $N$-acetylpenicillamine. $\mathrm{MPP}^{+}$itself was not toxic to the cells, but reduced respiratory efficiency as evidenced by a slight acidification of the cell culture medium. In spite of this, $\mathrm{MPP}^{+}$did not influence the toxicity of $S$-nitroso- $N$ acetylpenicillamine. After exposure to $0.25 \mathrm{mM} S$-nitroso$N$-acetylpenicillamine (for $16 \mathrm{~h}), 1 \mathrm{mM} \mathrm{MPP}^{+}(30 \mathrm{~h})$ and $0.25 \mathrm{mM} S$-nitroso- $N$-acetylpenicillamine (for $16 \mathrm{~h}$ ) $/ 1$ $\mathrm{mM} \mathrm{MPP}^{+}(30 \mathrm{~h})$, percentage cell death was $43.0 \pm 3.2 \%$, $1.5 \pm 1.2 \%$ and $35.5 \pm 3.7 \%$ (mean \pm S.E.M., $n=3$ ), respectively.

\subsection{Effect of deferoxamine, a cell permeable iron chelator,} on cell death induced by $S$-nitroso- $N$-acetylpenicillamine or sodium nitroprusside

In a preliminary experiment, it had been found that deferoxamine was toxic to CHP212 cells. Therefore, the effect of deferoxamine on cell death induced by $S$-nitroso$\mathrm{N}$-acetylpenicillamine was studied in PC12 cells as well. Viability was assessed by the ability of the cells to convert MTT, since the annexin V-FITC binding/propidium iodide uptake assay was not tested in PC12 cells. Deferoxamine was able to block the effect of sodium nitroprusside on viability in PC12 cells almost completely, whereas it did not attenuate the effect of $S$-nitroso- $N$-acetylpenicillamine (Fig. 7). Deferoxamine was quite toxic to CHP212 cells (Fig. 7). Surprisingly, the combination of sodium nitroprusside and deferoxamine was less toxic than each of the substances were separately, indicating that these substances had the ability to protect from each other (Fig. 7). When deferoxamine and $\mathrm{Fe}^{2+}$ were added in equimolar concentrations the former was not toxic anymore nor did it protect from sodium nitroprusside (data not shown), indicating that it was the iron chelating property of deferoxamine that was protective.

\subsection{Decomposition of S-nitroso- $N$-acetylpenicillamine and sodium nitroprusside}

From the above it is clear that there are important differences in the toxic molecules generated from $S$ nitroso- $N$-acetylpenicillamine and sodium nitroprusside that are responsible for the cell death observed. In addition to the above results, clues can be obtained from the literature as to what these reactive molecules might be. It was deemed important, however, to study some aspects of the decomposition of $S$-nitroso- $N$-acetylpenicillamine and sodium nitroprusside for our cell culture conditions. Decomposition of $S$-nitroso- $N$-acetylpenicillamine was followed spectrophotometrically. In the incubation medium, $S$-nitroso- $N$-acetylpenicillamine did not decompose spontaneously (Fig. 8A). Dithiothreitol and ascorbate caused decomposition of $S$-nitroso- $N$-acetylpenicillamine (Fig. 8A). $S$-nitroso- $N$-acetylpenicillamine $(0.25 \mathrm{mM})$ did not show any decomposition for $4 \mathrm{~h}$ in the presence of $1.5 \mathrm{mM}$ uric acid or $25 \mu \mathrm{M}$ oxyhemoglobin (data not shown). Decomposition of sodium nitroprusside was assessed by the formation of a red complex between 1,10-phenanthroline and $\mathrm{Fe}^{2+}$ in the incubation medium (serum was left out because $\mathrm{Fe}^{2+}$ binds to protein otherwise). Sodium nitroprusside did not decompose spontaneously. Sodium nitroprusside formed a red product with dithiothreitol. Both the red product and the complex have almost the same spectral characteristics. The red product decomposed with a half-life of approximately 2 min at $37^{\circ} \mathrm{C}$ (Fig. 8B), whereas the complex is stable. Subtraction of the absorbance of the red product from the total absorbance yields the absorbance by the complex and allows to assess how much $\mathrm{Fe}^{2+}$ is released from sodium nitroprusside. As judged from the release of $\mathrm{Fe}^{2+}, 8.9 \pm 0.4 \%$ (mean \pm S.E.M., $n=3$ ) of sodium nitroprusside was decomposed, half of which occurred in about $2 \mathrm{~min}$ (Fig. 2B). Even less $\mathrm{Fe}^{2+}$ was released from $0.5 \mathrm{mM}$ sodium nitroprusside in the presence of $0.5 \mathrm{mM}$ ascorbic acid, that is $3.39 \pm 0.11 \%$ (mean \pm S.E.M., $n=3$ ), half of which occurred in about $100 \mathrm{~min}$. Therefore, $>90 \%$ of sodium nitroprusside re-
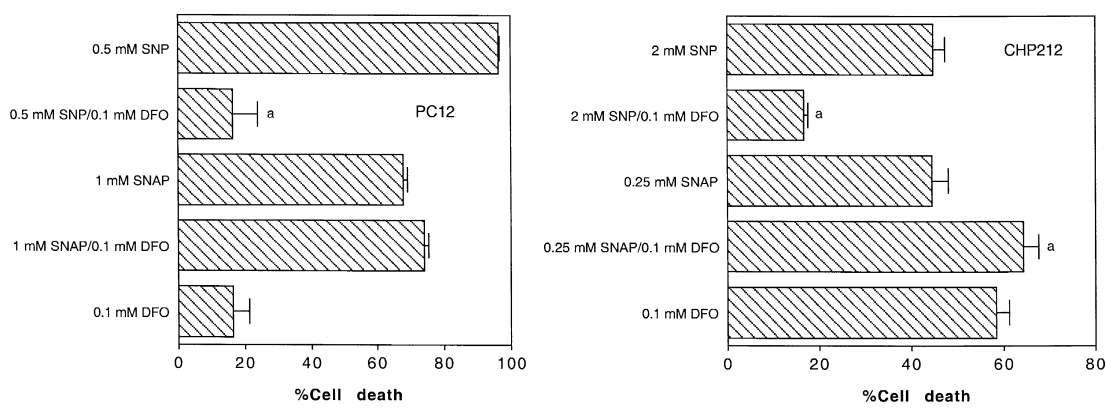

Fig. 7. Effect of deferoxamine (DFO) on cell death induced by sodium nitroprusside (SNP) or $S$-nitroso- $N$-acetylpenicillamine (SNAP) in PC12 and CHP212 cells. Cell death is defined here as the decrease in MTT reduction. Cells were preincubated with deferoxamine for $6 \mathrm{~h}$ and exposed to sodium

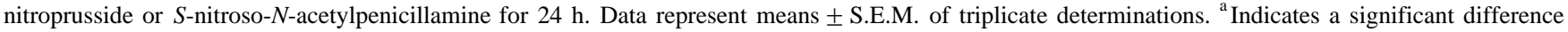
from the condition with sodium nitroprusside or $S$-nitroso- $N$-acetylpenicillamine alone $(P<0.05)$. Exposure to deferoxamine did not induce a significant fraction of dead PC12 cells, but did induce a significant fraction of dead CHP212 cells. 

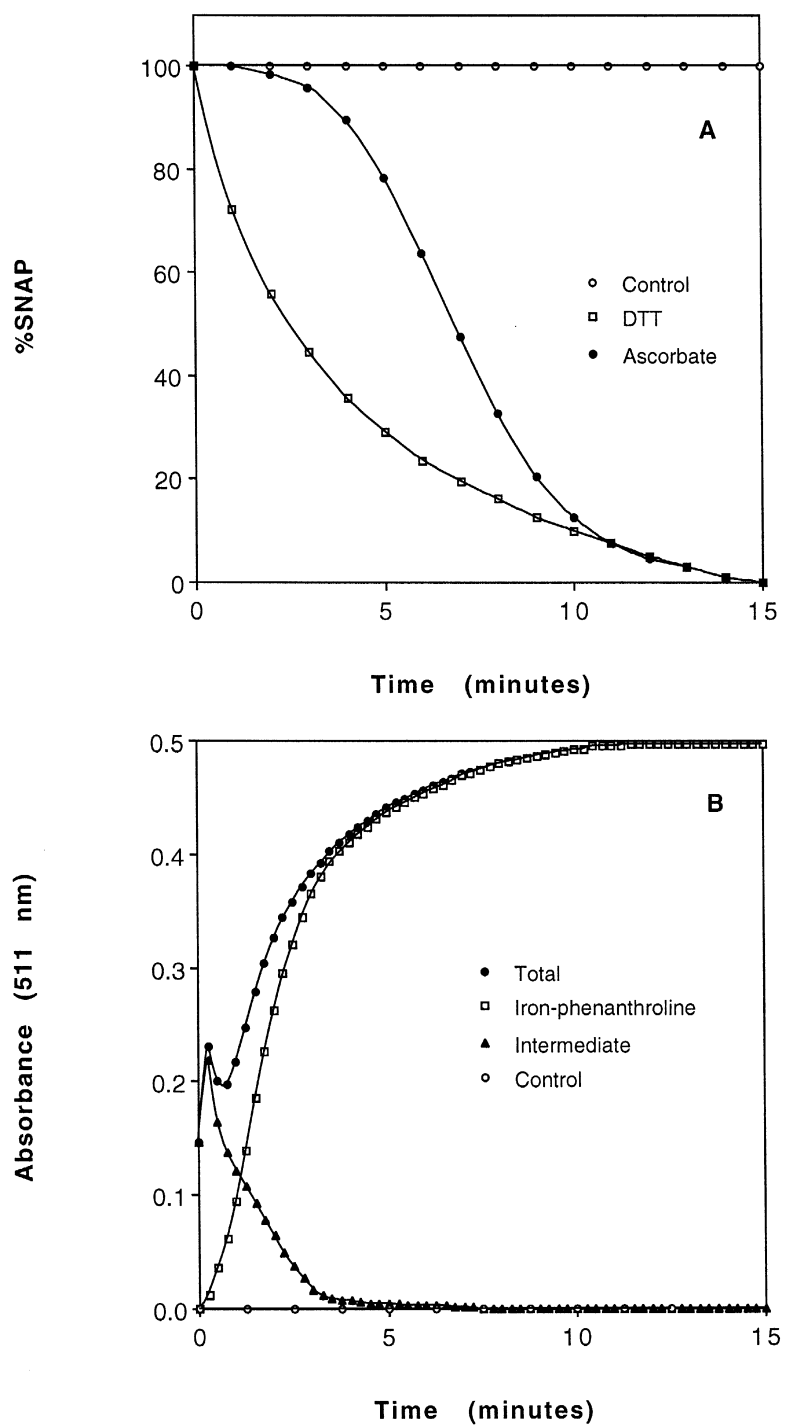

Fig. 8. Decomposition of $S$-nitroso- $N$-acetylpenicillamine (SNAP) in the presence of dithiothreitol (DTT) or ascorbate, and sodium nitroprusside (SNP) in the presence of dithiothreitol. (A) Disappearance of $S$-nitroso$\mathrm{N}$-acetylpenicillamine in the presence of dithiothreitol as measured spectrophotometrically at $335 \mathrm{~nm}$. The concentrations of $S$-nitroso- $N$-acetylpenicillamine, dithiothreitol and ascorbate were $0.25,0.5$ and $0.5 \mathrm{mM}$, respectively. (B) Change in the absorbance at $511 \mathrm{~nm}$ due to the formation of a red reaction product between sodium nitroprusside and dithiothreitol (closed triangles), formation of this red product and release of $\mathrm{Fe}^{2+}$ from sodium nitroprusside complexed to 1,10-phenanthroline (closed circles). Change in absorbance due to complex formation is indicated by open squares. The concentrations of sodium nitroprusside and 1,10-phenanthroline were 0.5 and $4 \mathrm{mM}$, respectively. Molar extinction of the 1,10-phenanthroline-iron complex was $11 \mathrm{M}^{-1} \mathrm{~cm}^{-1}$.

mained intact in the presence of each of the reductants. Because the red product was not present after $5 \mathrm{~min}$ anymore, it can be concluded that $>90 \%$ of the dithiothreitol disappeared by redox cycling with the concomitant production of $\mathrm{O}_{2}^{--}$from $\mathrm{O}_{2}$. Sodium nitroprusside $(0.5$ $\mathrm{mM}$ ) did not release any $\mathrm{Fe}^{2+}$ for $4 \mathrm{~h}$ in the absence of a reductant, or in the presence of $1.5 \mathrm{mM}$ uric acid or 25 $\mu \mathrm{M}$ oxyhemoglobin (data not shown).

$S$-nitroso- $N$-acetylpenicillamine decomposed in the presence of cells as determined by the accumulation of $\mathrm{NO}_{2}^{-}$(Fig. 9). In the presence of $S$-nitroso- $N$-acetylpenicillamine/dithiothreitol the accumulation of $\mathrm{NO}_{2}^{-}$was accelerated as compared to the presence of $S$-nitroso- $N$ acetylpenicillamine alone (Fig. 9, see also above). Decomposition of sodium nitroprusside in the presence of cells yielded substantially lower concentrations of $\mathrm{NO}_{2}^{-}$than decomposition of $S$-nitroso- $N$-acetylpenicillamine (Fig. 9). In the presence of sodium nitroprusside/dithiothreitol a short burst in the production of $\mathrm{NO}_{2}^{-}$was observed before $t=0.5 \mathrm{~h}$ (Fig. 9). Remarkably, production of $\mathrm{NO}_{2}^{-}$in the presence of sodium nitroprusside/dithiothreitol continued for a much longer period than would be expected on the basis of $\mathrm{Fe}^{2+}$ release from sodium nitroprusside in the presence of dithiothreitol (Fig. 8A). This could be due to transnitrosylation reactions and/or continued decomposition of sodium nitroprusside by the cells. $\mathrm{NO}_{2}^{-}$accounted for $60.9 \%$ of $S$-nitroso- $N$-acetylpenicillamine. $\mathrm{NO}_{x}^{-}$could be determined only in the samples in which decomposition of $S$-nitroso- $N$-acetylpenicillamine was complete, because the NADPH needed for reduction of $\mathrm{NO}_{3}^{-}$also reduced $S$-nitroso- $N$-acetylpenicillamine. Decomposition of $S$ nitroso- $\mathrm{N}$-acetylpenicillamine resulted in the formation of some $\mathrm{NO}_{3}^{-}\left(\mathrm{NO}_{2}^{-}\right.$concentration was $152.2 \pm 2.4 \mu \mathrm{M}$, $\mathrm{NO}_{x}^{-}$concentration was $198.4 \pm 7.7 \mu \mathrm{M}$ (mean \pm S.E.M., $n=3)$ at $48 \mathrm{~h}$ ). Total accumulation of $\mathrm{NO}_{x}^{-}$accounted for $79.4 \%$ of $S$-nitroso- $N$-acetylpenicillamine. Concentrations of $\mathrm{NO}_{x}^{-}$released from sodium nitroprusside could not be determined, since assay conditions led to further decomposition of sodium nitroprusside.

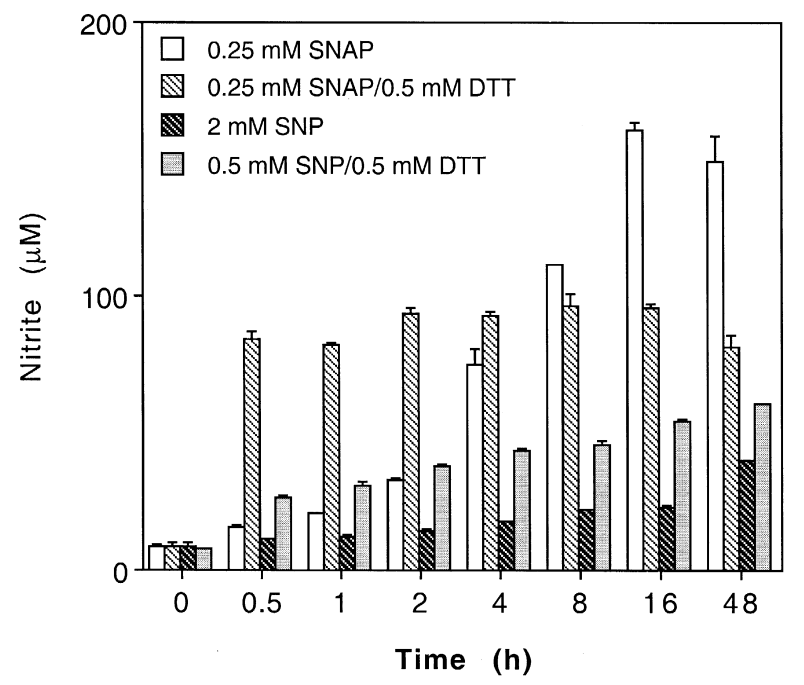

Fig. 9. $\mathrm{NO}_{2}^{-}$production from sodium nitroprusside (SNP) or $S$-nitroso$\mathrm{N}$-acetylpenicillamine (SNAP) in cell culture conditions in the presence and absence of dithiothreitol (DTT). $\mathrm{NO}_{2}^{-}$was determined with the Griess reagent. 
Table 1

Production of $\mathrm{NO}_{2}^{-}(\mu \mathrm{M})$ from sodium nitroprusside and $S$-nitroso- $N$-acetylpenicillamine, and decomposition of sodium nitroprusside and $S$-nitroso- $N$ acetylpenillamine as determined by the production of ferrocyanide $(\mu \mathrm{M})$ and absorbance at $335 \mathrm{~nm}$, respectively

\begin{tabular}{|c|c|c|c|c|}
\hline \multirow[t]{2}{*}{ Time (h) } & \multicolumn{2}{|c|}{ Sodium nitroprusside } & \multicolumn{2}{|c|}{$S$-nitroso- $N$-acetylpenicillamine } \\
\hline & $\overline{\mathrm{NO}_{2}^{-}}$ & Ferrocyanide & $\overline{\mathrm{NO}_{2}^{-}}$ & Absorbance $(335 \mathrm{~nm})$ \\
\hline 4 & $6.6 \pm 0.4$ & - & $74.7 \pm 6.3$ & $0.119 \pm 0.003(49.0 \%)^{\mathrm{a}}$ \\
\hline 48 & $28.8 \pm 1.8$ & $126.7 \pm 7.0(9.5 \%)$ & $140.9 \pm 9.1$ & $0.000 \pm 0.000(0.0 \%)$ \\
\hline
\end{tabular}

The absorbance of $0.25 \mathrm{mM} S$-nitroso- $N$-acetylpenicillamine at $335 \mathrm{~nm}$ in cell culture medium was $0.239 \pm 0.0014$.

Data represent means \pm S.E.M. of triplicate determinations.

${ }^{a}$ Indicates percentage $S$-nitroso- $N$-acetylpenicillamine remaining.

${ }^{\mathrm{b}}$ Indicates percentage decomposition calculated from ferrocyanide production.

Table 1 gives the time dependent production of $\left[\mathrm{Fe}(\mathrm{CN})_{6}\right]^{4-}$ from sodium nitroprusside and the absorbance of remaining $S$-nitroso- $N$-acetylpenicillamine in the presence of cells. As judged from the production of $\left[\mathrm{Fe}(\mathrm{CN})_{6}\right]^{4-}$ much more sodium nitroprusside was decomposed than $\mathrm{NO}_{2}^{-}$could account for. Production of $\mathrm{NO}_{2}^{-}$ paralleled the disappearance of $S$-nitroso- $N$-acetylpenicillamine.

\subsection{Effect of decomposition products of sodium nitroprus- side on cell death}

As found in the present study and also reported by others (Bates et al., 1991; Rao et al., 1991) decomposition products of sodium nitroprusside in addition to NO include $\mathrm{CN}^{-}, \mathrm{Fe}^{2+}$ and $\left[\mathrm{Fe}(\mathrm{CN})_{6}\right]^{4-}$. Ascorbic acid and dithiothreitol were used to accelerate the decomposition of sodium nitroprusside. Ascorbic acid, dithiothreitol, $\mathrm{CN}^{-}$,
$\mathrm{Fe}^{2+},\left[\mathrm{Fe}(\mathrm{CN})_{6}\right]^{4-}$ and $\left[\mathrm{Fe}\left(\mathrm{CN}_{6}\right)\right]^{3-}$ at concentrations indicated in Table 2 were not toxic to the cells. Combinations of concentrations of $\mathrm{Fe}^{2+}$ and $\mathrm{CN}^{-}$that can be released by $0.5 \mathrm{mM}$ dithiothreitol or $0.5 \mathrm{mM}$ ascorbic acid from $0.5 \mathrm{mM}$ sodium nitroprusside (see Section 3.6), either alone or in combination with the reductant, were not toxic as well (Table 2). However, the combination $\mathrm{Fe}^{2+} /$ $\mathrm{CN}^{-}$/ascorbic acid potentiated the effect of $\mathrm{H}_{2} \mathrm{O}_{2}$, whereas the combination $\mathrm{Fe}^{2+} / \mathrm{CN}^{-} /$dithiothreitol did not. The extra toxicity of sodium nitroprusside/ascorbic acid as compared to sodium nitroprusside/dithiothreitol (Table 2) probably can be explained by the pro-oxidant action of $\mathrm{Fe}^{2+} /$ ascorbic acid. It did not make any difference whether sodium nitroprusside/dithiothreitol was removed after 0.5 $\mathrm{h}$ or whether sodium nitroprusside/dithiothreitol was present throughout the incubation period of $16 \mathrm{~h}$ (Table 2), indicating that further metabolism of sodium nitroprusside after $0.5 \mathrm{~h}$ did not contribute to the toxic effect.

Table 2

Effect of sodium nitroprusside and reductants or substances produced in the presence of sodium nitroprusside and reductants on cell death

\begin{tabular}{lc}
\hline Condition & \%Cell death \\
\hline Control & $0.0 \pm 3.8$ \\
Ascorbic acid $(0.5 \mathrm{mM})$ & $1.5 \pm 2.7$ \\
Dithiothreitol $(0.5 \mathrm{mM})$ & $-1.9 \pm 0.0$ \\
$\mathrm{Fe}^{2+}(0.25 \mathrm{mM})$ & $5.7 \pm 3.0$ \\
$\mathrm{CN}^{-}(1.25 \mathrm{mM})$ & $2.8 \pm 0.3$ \\
{$\left[\mathrm{Fe}(\mathrm{CN})_{6}\right]^{4-}(0.25 \mathrm{mM})$} & $5.8 \pm 6.9$ \\
{$\left[\mathrm{Fe}(\mathrm{CN})_{6}\right]^{3-}(0.25 \mathrm{mM})$} & $2.8 \pm 0.5$ \\
$\mathrm{Fe}^{2+}(20 \mu \mathrm{M}) / \mathrm{CN}^{-}(60 \mu \mathrm{M}) /$ ascorbic acid $(0.5 \mathrm{mM})$ & $0.2 \pm 1.2$ \\
$\mathrm{Fe}^{2+}(50 \mu \mathrm{M}) / \mathrm{CN}^{-}(150 \mu \mathrm{M}) /$ dithiothreitol $(0.5 \mathrm{mM})$ & $0.0 \pm 3.3$ \\
$\mathrm{H}_{2} \mathrm{O}_{2}(0.25 \mathrm{mM})$ & $36.0 \pm 7.7^{\mathrm{a}}$ \\
$\mathrm{Fe}^{2+}(20 \mu \mathrm{M}) / \mathrm{CN}^{-}(60 \mu \mathrm{M}) /$ ascorbic acid $(0.5 \mathrm{mM}) / \mathrm{H}_{2} \mathrm{O}_{2}(0.25 \mathrm{mM})$ & $62.9 \pm 2.5^{\mathrm{a}}$ \\
$\mathrm{Fe}^{2+}(50 \mu \mathrm{M}) / \mathrm{CN}^{-}(150 \mu \mathrm{M}) /$ dithiothreitol $(0.5 \mathrm{mM}) / \mathrm{H}_{2} \mathrm{O}_{2}(0.25 \mathrm{mM})$ & $31.7 \pm 7.7^{\mathrm{a}}$ \\
sodium nitroprusside $(0.5 \mathrm{mM}) /$ ascorbic acid $(0.5 \mathrm{mM})(16 \mathrm{~h})$ & $51.9 \pm 4.3^{\mathrm{a}}$ \\
sodium nitroprusside $(0.5 \mathrm{mM}) /$ dithiothreitol $(0.5 \mathrm{mM})(16 \mathrm{~h})$ & $27.5 \pm 0.6^{\mathrm{a}, \mathrm{b}}$ \\
sodium nitroprusside $(0.5 \mathrm{mM}) /$ dithiothreitol $(0.5 \mathrm{mM})(0.5 \mathrm{~h}) ;-(15.5 \mathrm{~h})$ & $31.3 \pm 3.2^{\mathrm{a}}$ \\
\hline
\end{tabular}

The concentrations $\mathrm{Fe}^{2+}$ and $\mathrm{CN}^{-}$in the combinations with ascorbic acid or dithiothreitol are based on the concentrations $\mathrm{Fe}^{2+}$ measured as released from $0.5 \mathrm{mM}$ sodium nitroprusside by $0.5 \mathrm{mM}$ ascorbic acid or $0.5 \mathrm{mM}$ dithiothreitol. CHP212 cells were exposed to the above substances for $16 \mathrm{~h}$ unless otherwise indicated. Data represent means \pm S.E.M. of triplicate determinations.

${ }^{\mathrm{a}}$ Indicates a significant difference from control.

${ }^{\mathrm{b}}$ Indicates a significant difference from the effect of sodium nitroprusside/ascorbic acid. 


\section{Discussion}

\subsection{S-nitroso-N-acetylpenicillamine and sodium nitroprus-} side induce apoptosis in CHP212 cells

In the present study the annexin V-FITC binding/propidium iodide uptake assay was used to monitor apoptotic and necrotic cell death. Apoptotic cells expose phosphatidylserine residues at their outer plasma membrane leaflet, before membrane integrity is lost. The apoptotic state of a cell can be visualized by binding of annexin V-FITC to phosphatidylserine and exclusion of the DNAintercalating dye propidium iodide. By contrast, in primary necrotic and secondary necrotic cells, phosphatidylserine residues at the inner plasma membrane will become accessible to annexin $\mathrm{V}$ as soon as the cells lose their membrane integrity. Therefore, a primary necrotic or secondary necrotic cell will bind annexin $\mathrm{V}$ and stain with propidium iodide. Microscopically, primary necrotic cells are characterized by a diffuse nuclear morphology, whereas apoptotic cells and secondary necrotic cells are characterized by their typical nuclear fragmentation.

It was shown in the present study that cell death in cultures exposed to relative low concentrations $S$-nitroso$\mathrm{N}$-acetylpenicillamine, sodium nitroprusside or $\mathrm{H}_{2} \mathrm{O}_{2}$ was primarily of the apoptotic type. In the presence of 0.25 $\mathrm{mM} S$-nitroso- $N$-acetylpenicillamine, first annexin V-FITC binding cells appeared, which at a later stage showed propidium iodide uptake. In the presence of $0.5 \mathrm{mM}$ sodium nitroprusside or $0.5 \mathrm{mM} \mathrm{H}_{2} \mathrm{O}_{2}$ the shift from apoptosis to secondary necrosis was less clear or not clear at all, although microscopic analysis showed that cell death for the most part was of the apoptotic type. At relatively high concentrations of $S$-nitroso- $N$-acetylpenicillamine or $\mathrm{H}_{2} \mathrm{O}_{2}$, CHP212 cells became primary necrotic. The phenomenon that cells can become apoptotic or primary necrotic depending on the intensity of the insult has been described by Whittemore et al. (1995) and Kaal et al. (1998) for cortical neurons exposed to $\mathrm{H}_{2} \mathrm{O}_{2}$ and motoneurons exposed to $\mathrm{Fe}(\mathrm{III}) /$ ascorbate, respectively. Whittemore et al. (1995) showed that exposure to $\mathrm{H}_{2} \mathrm{O}_{2}$ resulted in loss of mitochondrial activity. It is quite conceivable that extensive loss of mitochondrial activity caused by high concentrations of $\mathrm{H}_{2} \mathrm{O}_{2}$ or NO may impair the ability of the cell to become apoptotic, since apoptosis requires energy (e.g. Leist et al., 1997).

\subsection{Decomposition of S-nitroso-N-acetylpenicillamine and sodium nitroprusside}

In our culture conditions $\mathrm{NO}$ was released faster from $S$-nitroso- $N$-acetylpenicillamine than from sodium nitroprusside. This may explain the slower onset of the effect of sodium nitroprusside on apoptosis in CHP212 cells. Both $S$-nitroso- $N$-acetylpenicillamine and sodium nitroprusside were shown not to decompose spontaneously in tissue culture medium. However, these compounds decomposed in the presence of cells. This is in agreement with data from Gordge et al. (1998), who reported that different cell types enhanced the decomposition of $S$-nitrosoglutathione, which was ascribed to the activity of a $S$-nitrosoglutathione lyase. The decomposition of $S$-nitroso- $N$-acetylpenicillamine appeared to be at an extracellular site, since the formation of apoptotic cells could be blocked by cell impermeable oxyhemoglobin. This suggests that the putative $S$-nitrosothiollyase is an extracellular enzyme. Findings from several laboratories indicate that NO is released from sodium nitroprusside after cellular internalization (e.g. Bates et al., 1991; Rao et al., 1991). The finding that oxyhemoglobin, catalase and superoxide dismutase, which are all three cell impermeable, did not inhibit the toxicity of sodium nitroprusside also favor this notion. Deferoxamine was able to protect cells from sodium nitroprusside, but deferoxamine is a cell permeable compound. Most of the NO released from $S$-nitroso- $N$-acetylpenicillamine in the presence of cells was converted to $\mathrm{NO}_{2}^{-}$, which is formed by the reaction of $\mathrm{NO}$ and $\mathrm{O}_{2}^{--}$. Accumulation of $\mathrm{NO}_{2}^{-}$ accounted for less than $15 \%$ of the decomposition of sodium nitroprusside in the presence of cells. Most of the NO released from sodium nitroprusside, therefore, did not appear to be converted to $\mathrm{NO}_{2}^{-}$, suggesting a different fate of $\mathrm{NO}$, possibly conversion to $\mathrm{NO}_{3}^{-}$with $\mathrm{ONOO}^{-}$as intermediate.

Although sodium nitroprusside is used as a NO donor it has been reported by several laboratories that sodium nitroprusside can be decomposed to a number of other toxic compounds that may be toxic themselves (e.g. Bates et al., 1991; Rao et al., 1991). Moreover, sodium nitroprusside may participate in redox cycling with the production of $\mathrm{O}_{2}^{--}$(e.g. Bates et al., 1991; Rao et al., 1991). According to our findings, the production of $\mathrm{O}_{2}^{--}$and $\mathrm{H}_{2} \mathrm{O}_{2}$ from sodium nitroprusside in the presence of a reductant is more important than the production of NO. During decomposition of sodium nitroprusside, $\left[\mathrm{Fe}(\mathrm{CN})_{5} \mathrm{NO}\right]^{3-}$ can be formed. $\mathrm{NO}$ can be formed from this intermediate according to:

$$
\begin{aligned}
& {\left[\mathrm{Fe}(\mathrm{CN})_{5} \mathrm{NO}\right]^{3-} \rightarrow\left[\mathrm{Fe}(\mathrm{CN})_{4} \mathrm{NO}\right]^{2-}+\mathrm{CN}^{-} \rightarrow} \\
& 3\left[\mathrm{Fe}(\mathrm{CN})_{4} \mathrm{NO}\right]^{2-} \rightarrow 2\left[\mathrm{Fe}(\mathrm{CN})_{6}\right]^{4-}+\mathrm{Fe}^{2+}+3 \mathrm{NO}
\end{aligned}
$$

However, $\left[\mathrm{Fe}(\mathrm{CN})_{5} \mathrm{NO}\right]^{3-}$ can react with oxygen according to:

$$
\begin{aligned}
& {\left[\mathrm{Fe}(\mathrm{CN})_{5} \mathrm{NO}\right]^{3-}+\mathrm{O}_{2}} \\
& \quad \rightarrow\left[\mathrm{Fe}(\mathrm{CN})_{5} \mathrm{NO}\right]^{2-} \text { (nitroprusside) }+\mathrm{O}_{2}^{--}
\end{aligned}
$$

From our results it can be concluded that reaction (3) is much more prevalent than reaction (2).

\section{3. $\mathrm{ONOO}^{-}$may not be involved in apoptosis induced by $\mathrm{S}$-nitroso- $\mathrm{N}$-acetylpenicillamine}

To assess the involvement of $\mathrm{ONOO}^{-}$in the toxicity of $S$-nitroso- $N$-acetylpenicillamine and sodium nitroprusside 
towards CHP212 cells, urate was used as a $\mathrm{ONOO}^{-}$ scavenger (e.g. Szabo and Salzman, 1995; Xie and Wolin, 1996). Urate did not protect the cells against either $S$ nitroso- $N$-acetylpenicillamine or sodium nitroprusside, suggesting that $\mathrm{ONOO}^{-}$was not involved in the cell death found, whereas some protection of urate against SIN-1 was observed. It should be mentioned, however, that ascorbate and dithiothreitol can react with $\mathrm{ONOO}^{-}$as well (Radi et al., 1991; Shi et al., 1994), and were protective. Ascorbate and dithiothreitol, but not urate, increased the rate of decomposition of $S$-nitroso- $N$-acetylpenicillamine. Increased rate of decomposition of $S$-nitroso- $N$-acetylpenicillamine could reduce the toxicity of $S$-nitroso- $N$-acetylpenicillamine towards CHP212 cells. CHP212 cells may be able to withstand short durations of exposure to high concentrations of NO. During this time, apparently no irreversible damage is done to the cell. Just recently, Clementi et al. (1998) showed that the sustained presence of $\mathrm{NO}$, without the involvement of $\mathrm{ONOO}^{-}$, causes persistent inhibition of cell respiration by $S$-nitrosylation of mitochondrial complex I. Apoptosis induced by $\mathrm{NO}$ in CHP212 cells might also cause $S$-nitrosylation without involvement of $\mathrm{ONOO}^{-}$, although the molecular target(s) in this case are not known as yet.

In our cell culture conditions SIN-1 was more toxic in the presence than in the absence of superoxide dismutase and catalase. Superoxide dismutase and catalase reduce the production of $\mathrm{ONOO}^{-}$in favor of the formation of NO. From this is can be concluded that $\mathrm{ONOO}^{-}$is not more toxic to CHP212 cells than NO. Surprisingly, $S$-nitroso- $N$ acetylpenicillamine was more toxic than $\mathrm{SIN}-1 /$ superoxide dismutase/catalase. This may be related to the fact that SIN-1 decomposes spontaneously (with a reported half-life of about $2 \mathrm{~h}$ ) (Pfeiffer and Mayer, 1998) and to the finding that $S$-nitroso- $N$-acetylpenicillamine requires the presence of cells to decompose. Consequently, $S$ nitroso- $N$-acetylpenicillamine may cause a higher flux of $\mathrm{NO}$ in the vicinity of cells than SIN-1/superoxide dismutase/catalase.

Finally we increased the production of endogeneous $\mathrm{O}_{2}^{--}$by exposure of the cells to $\mathrm{MPP}^{+}$. This did not increase the toxicity of $S$-nitroso- $N$-acetylpenicillamine, which would not be expected were the production of $\mathrm{ONOO}^{-}$be involved. Indeed, it has been shown that $\mathrm{MPP}^{+}$causes NO to become toxic to dopaminergic neurons (Sawada et al., 1996), suggesting a role for $\mathrm{ONOO}^{-}$ in this case.

Several studies have addressed the issue whether it is NO, be it produced endogenously or derived from a donor, or the metabolite $\mathrm{ONOO}^{-}$that is the toxic species. The finding that MnTBAP (Mn(III)tetrakis(4-benzoic acid)porphyrin chloride) protects cells from NO-induced in some cases has been taken as evidence for a role of $\mathrm{ONOO}^{-}$(e.g. Arstall et al., 1999), although a direct role for $\mathrm{O}_{2}^{--}$cannot be excluded as well. In other cases, it seems that $\mathrm{NO}$ does not require conversion to $\mathrm{ONOO}^{-}$to become toxic. For instance, MnTBAP did not protect primary cultured motoneurons from NO-induced apoptosis (Kaal et al., 1999). Urate did not protect RAW 2647 macrophages against NO cytotoxicity, inspite of the finding that overexpression of $\mathrm{Cu}, \mathrm{Zn}$ superoxide dismutase was protective in this case (Brockhaus and Brune, 1999). Our study suggests that both $\mathrm{NO}$ and $\mathrm{ONOO}^{-}$can be toxic to CHP212 cells.

In principle several forms of $\mathrm{NO}$ could be responsible for cell death induced by $S$-nitroso- $N$-acetylpenicillamine, that is $\mathrm{NO}^{*}, \mathrm{NO}^{+}$or $\mathrm{NO}^{-}$. Several reasons favor a role for $\mathrm{NO}^{*}$ as the apoptosis inducing species, however. First, oxyhemoglobin, which only scavenges $\mathrm{NO}$, inhibited apoptosis induced by $S$-nitroso- $N$-acetylpenicillamine. Second, $\mathrm{NO}^{+}$is neither scavenged by oxyhemoglobin nor methemoglobin (Arnelle and Stamler, 1995). Third, the transnitrosylation of NO from $S$-nitroso- $N$-acetylpenicillamine to dithiothreitol can produce a $\mathrm{NO}^{-}$releasing species (Arnelle and Stamler, 1995), whereas dithiothreitol reduced the toxicity of $S$-nitroso- $N$-acetylpenicillamine. Admittedly, $\mathrm{NO}^{-}$is released fast from $S$-nitrosodithiothreitol, but so would it be from any $S$-nitrosodithiol that might be formed.

\section{4. $\mathrm{H}_{2} \mathrm{O}_{2}$ and / or iron may mediate apoptosis induced by sodium nitroprusside}

Sodium nitroprusside not only is a NO donor but releases several other potentially toxic products, including $\mathrm{CN}^{-}$and $\mathrm{Fe}^{2+}$ (e.g. Rao et al., 1991). These products by themselves, however, were not able to cause an appreciable number of apoptotic cells. In addition, sodium nitroprusside and decomposition products of sodium nitroprusside can participate in redox cycling reactions in the presence of a reductant, which has been shown by Rao et al. (1991). It could be shown that superoxide dismutase and catalase prevented the effect of sodium nitroprusside / dithiothreitol on the number of dead cells. This is evidence for the involvement of the production of $\mathrm{O}_{2}^{--}$and $\mathrm{H}_{2} \mathrm{O}_{2}$ in cell death mediated by sodium nitroprusside/dithiothreitol or in cell culture conditions. The observation that superoxide dismutase and catalase did not protect from sodium nitroprusside without dithiothreitol (actually superoxide dismutase somewhat potentiated toxicity), might be explained by the fact that superoxide dismutase and catalase cannot enter the cell. The small potentiating effect of superoxide dismutase on apoptosis induced by sodium nitroprusside remains difficult to explain.

Without the presence of an external reductant the reducing power for decomposition of sodium nitroprusside has to be provided by the cell. It was argued above that sodium nitroprusside probably has to be taken up by the cell to be decomposed. In principle, sodium nitroprusside can generate $\mathrm{NO}, \mathrm{O}_{2}^{--}, \mathrm{H}_{2} \mathrm{O}_{2}, \mathrm{CN}^{-}$and $\mathrm{Fe}^{2+}$ inside the cell. Evidence was obtained that $\mathrm{Fe}^{2+}$ is involved in the apop- 
tosis induced by sodium nitroprusside. Chelation of iron by a cell permeable iron chelator, deferoxamine, abrogated the toxic effect of sodium nitroprusside in both CHP212 and $\mathrm{PC} 12$ cells. It is known from the literature that $\mathrm{H}_{2} \mathrm{O}_{2}$ requires the presence of iron to become toxic (e.g. Starke and Farber, 1985). Interestingly, both deferoxamine and sodium nitroprusside were toxic to CHP212 cells, whereas the combination of the two was less toxic than each of the substances separately. Deferoxamine probably is toxic because iron is necessary for normal physiological functioning (e.g. Blatt and Stitely, 1987). The protective effect of sodium nitroprusside against deferoxamine suggests that sodium nitroprusside delivers iron to the cell either in concentrations that are not toxic, or at sites where it is not toxic but where it can sustain physiological functioning.

Additional arguments can be given here to support the notion that sodium nitroprusside has to be taken up by the cell to become toxic. If $\mathrm{Fe}^{2+}$ were to be generated outside the cell from sodium nitroprusside and to account for its toxicity extracellular $\mathrm{Fe}^{2+}$ would be toxic, but it was not. If $\mathrm{Fe}^{2+}$ required $\mathrm{H}_{2} \mathrm{O}_{2}$ generated outside the cell from sodium nitroprusside catalase would be protective, but it was not.

\subsection{Final remarks and conclusions}

With respect to the toxicity of sodium nitroprusside towards neuronal cells some additional remarks should be made. Lipton et al. (1993) previously observed that the toxicity of sodium nitroprusside is increased by ascorbic acid or dithiothreitol. They explained this by the fact that in the presence of reductants the release of NO from sodium nitroprusside is increased. In the light of our results this explanation does not seem to be valid anymore. It has also been proposed that sodium nitroprusside is a donor of $\mathrm{NO}^{+}$, whereas $S$-nitroso- $N$-acetylpenicillamine is not (Messmer et al., 1995; Vallette et al., 1996; Khan et al., 1997). This could explain different actions of the two donors. This notion also has to be considered with care in view of the evidence that $\mathrm{Fe}^{2+}$ and/or $\mathrm{H}_{2} \mathrm{O}_{2}$ mediated the toxicity of sodium nitroprusside in CHP212 cells. Moreover, $\mathrm{NO}^{+}$is immediately hydrolysed to $\mathrm{NO}_{2}^{-}$under physiological and cell culture conditions (Butler et al., 1995).

Our data are compatible with the schematic representation in Fig. 10. NO formed at a distance from the cell is not toxic, probably because it is converted to $\mathrm{NO}_{2}^{-}$or $\mathrm{NO}_{3}^{-}$before it is able to reach the cell. NO formed in close vicinity to the cell may be able to induce apoptosis. Sodium nitroprusside probably has to be taken up by the cell for decomposition and intracellularly it can generate $\mathrm{H}_{2} \mathrm{O}_{2}$. $\mathrm{ONOO}^{-}$does not appear to be directly involved in apoptosis induced by sodium nitroprusside or $S$-nitroso- $N$ acetylpenicillamine in CHP212 cells.

In conclusion, our results show that $S$-nitroso- $N$ acetylpenicillamine and sodium nitroprusside can induce a

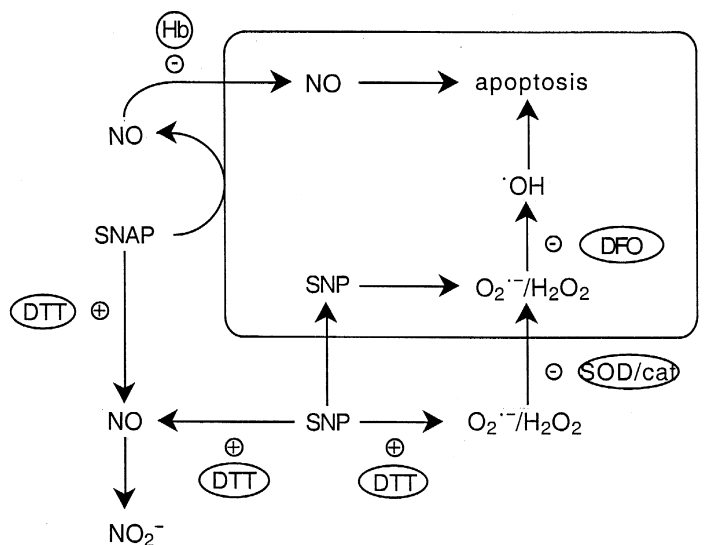

Fig. 10. Schematic representation of production of reactive oxygen species by sodium nitroprusside (SNP) and $S$-nitroso- $N$-acetylpenicillamine (SNAP) in the presence of cells, with and without dithiothreitol (DTT), leading to apoptosis. Places where different agents influence the decomposition or inhibit the action of sodium nitroprusside and $S$-nitroso$\mathrm{N}$-acetylpenicillamine are indicated. Dithiothreitol accelerates the decomposition of $S$-nitroso- $N$-acetylpenicillamine and sodium nitroprusside. Hemoglobin (Hb) blocks the action of $S$-nitroso- $N$-acetylpenicillamine. Superoxide dismutase (SOD), catalase (cat) and deferoxamine (DFO) inhibit the action of sodium nitroprusside.

type of cell death in a neuroblastoma line that is indistinguishable from apoptosis. However, $S$-nitroso- $N$-acetylpenicillamine and sodium nitroprusside induced apoptosis at different concentrations and with different time courses. The evidence suggests that sustained low fluxes of the NO appear to induce apoptosis in CHP212 cells. Moreover, it could be shown that $\mathrm{Fe}^{2+}$ and $\mathrm{H}_{2} \mathrm{O}_{2}$, rather than $\mathrm{NO}$, is involved in apoptosis induced by sodium nitroprusside. The model system developed for this study will be used in future studies to elucidate the mechanism of NO-induced apoptosis in neuronal cells.

\section{Acknowledgements}

This research was funded by the Prinses Beatrix Fonds (project number: 95-103).

\section{References}

Arnelle, D.R., Stamler, J.S., 1995. $\mathrm{NO}^{+}$, $\mathrm{NO}^{-}$and $\mathrm{NO}^{-}$donation by $S$-nitrosothiols: implications for regulation of pathological functions by $S$-nitrosylation and acceleration of disulfide formation. Arch. Biochem. Biophys. 318, 279-285.

Arstall, M.A., Sawyer, D.B., Fukazawa, R., Kelly, R.A., 1999. Cytokine-mediated apoptosis in cardiac myocytes: the role of inducible nitric oxide synthase induction and peroxynitrite generation. Circ. Res. 85, 829-840.

Bates, J.N., Baker, M.T., Guerra, R., Harrison, D.G., 1991. Nitric oxide generation from nitroprusside by vascular tissue: evidence that reduction of nitroprusside anion and cyanide loss are required. Biochem. Pharmacol. 42 (Suppl.), S157-S165.

Blanco, F.J., Ochs, R.L., Schwartz, H., Lotz, M., 1995. Chondrocyte apoptosis induced by nitric oxide. Am. J. Pathol. 46, 75-85. 
Blatt, J., Stitely, S., 1987. Antineuroblastoma activity of desferoxamine in human cell lines. Cancer Res. 47, 3968-3975.

Bolaños, J.P., Heales, S.J., Land, J.M., Clark, J.B., 1995. Effect of peroxynitrite on the mitochondrial respiratory chain: differential susceptibility of neurones and astrocytes in primary culture. J. Neurochem. 50, 1965-1972.

Bonfoco, E., Krainc, D., Ankarcrona, M., Nicotera, P., Lipton, S.A., 1995. Apoptosis and necrosis: two distinct events induced, respectively, by mild and intense insults with $N$-methyl-D-aspartateor nitric oxide/superoxide in cortical cell cultures. Proc. Natl. Acad. Sci. U. S. A. $92,7162-7166$.

Brockhaus, F., Brune, B., 1999. Overexpression of $\mathrm{Cu}, \mathrm{Zn}$ superoxide dismutase protects RAW 264.7 macrophages against nitric oxide cytotoxicity. Biochem. J. 338, 295-303.

Butler, A.R., Flitney, F.W., Williams, D.L.H., 1995. NO, nitrosonium ions, nitroxide ions, nitrosothiols and iron-nitrosyls in biology: a chemist's perspective. TIPS $16,18-22$.

Castro, L., Rodriguez, M., Radi, R., 1994. Aconitase is readily inactivated by peroxynitrite, but not its precursor nitric oxide. J. Biol. Chem. 269, 29409-29415.

Clementi, E., Brown, G.C., Feelisch, M., Moncada, S., 1998. Persistent inhibition of cell respiration by nitric oxide: crucial role of $S$-nitrosylation of mitochondrial complex I and protective action of glutathione. Proc. Natl. Acad. Sci. U. S. A. 95, 7631-7636.

Dawson, T.M., Dawson, V.L., 1995. Nitric oxide: actions and pathological roles. The Neuroscientist 1, 7-18.

Dawson, V.L., Dawson, T.M., London, E.D., Bredt, D.S., Snyder, S.H., 1991. Nitric oxide mediates glutamate neurotoxicity in primary cortical cultures. Proc. Natl. Acad. Sci. U. S. A. 88, 6368-6371.

Drapier, J.-C., Hibbs, J.B. Jr., 1988. Differentiation of murine macrophages to express nonspecific cytotoxicity for tumor cells results in L-arginine-dependent inhibition of mitochondrial iron-sulfur enzymes in the macrophage effector cells. J. Immunol. 140, 28292838.

Fehsel, K., Kroncke, K.D., Meyer, K.L., Huber, H., Wahn, V., KolbBachofen, V., 1995. Nitric oxide induces apoptosis in mouse thymocytes. J. Immunol. 155, 2858-2865.

Grisham, M.B., Johnson, G.G., Lancaster, J.R. Jr., 1996. Quantitation of nitrate and nitrite in extracellular fluids. Methods Enzymol. 268, $237-246$.

Gordge, M.P., Addis, P., Noronha-Dutra, A.A., Hothersall, J.S., 1998. Cell-mediated biotransformation of $S$-nitroglutathione. Biochem. Pharmacol. 55, 657-665.

Hartly, T.F., Philcox, J.C., Willoughby, J., 1985. Two methods for monitoring photodecomposition of sodium nitroprusside in aqueous and glucose solutions. J. Pharmacol. Sci. 74, 668-671.

Iadecola, C., 1997. Bright and dark sides of nitric oxide in ischemic brain injury. TINS 20, 132-139.

Kaal, E.C., Veldman, H., Sodaar, P., Joosten, E.A., Bär, P.R., 1998. Oxidant treatment causes a dose-dependent phenotype of apoptosis in cultured motoneurons. J. Neurosci. Res. 54, 778-786.

Kaal, E.C., Kil, A.C., Sodaar, P., Joosten, E.A., Bär, P.R., 1999. Cobalt prevents nitric oxide-induced apoptotic motoneuron death in vitro. NeuroReport 10, 2335-2339.

Kaneto, H., Fujii, J., Seo, H.G., Suzuki, K., Matsuoka, T., Nakamura, M., Tatsumi, H., Yamasaki, Y., Kamada, T., Tanaguchi, N., 1995. Apoptotic cell death triggered by nitric oxide in pancreatic beta-cells. Diabetes 44, 733-738.

Katsuki, S., Arnold, W., Mittal, C., Murad, F., 1977. Stimulation of guanylate cyclase by sodium nitroprusside, nitroglycerin and nitric oxide in various tissue preparations and comparison to the effects of sodium azide and hydroxylamine. J. Cyclic Nucleotide Res. 3, 23-25.

Khan, S., Kayahara, M., Joash, U., Mazarakis, N.D., Sarraf, C., Edwards, A.D., Hughes, M.N., Mehmet, H., 1997. Differential induction of apoptosis in Swiss 3T3 cells by nitric oxide and the nitrosonium cation. J. Cell Sci. 110, 2315-2322.

Leist, M., Single, B., Castoldi, A.F., Kuhnle, S., Nicotera, P., 1997.
Intracellular adenosine triphosphate (ATP) concentration: a switch in the decision between apoptosis and necrosis. J. Exp. Med. 185, $1481-1486$.

Lipton, S.A., Choi, Y.-B., Pan, Z.-H., Lei, S.Z., Chen, H.-S.V., Sucher, N.J., Loscalzo, J., Singel, D.J., Stamler, J.S., 1993. A redox-based mechanism for the neuroprotective and neurodestructive effects of nitric oxide and related nitroso-compounds. Nature 364, 626-632.

Messmer, U.K., Lapetina, E.G., Brune, B., 1995. Nitric oxide-induced apoptosis in RAW 264.7 macrophages is antagonized by protein kinase C- and protein kinase A-activating compounds. Mol. Pharmacol. 47, 757-765.

Mitrovic, B., Ignarro, L.J., Vinters, H.V., Akers, M.-A., Schmid, I., Uittenbogaart, C., Merrill, J.E., 1995. Nitric oxide induces necrotic but not apoptotic cell death in oligodendrocytes. Neuroscience 65, 531-539.

Mohr, S., Stamler, J.S., Brune, B., 1994. Mechanism of covalent modification of glyceraldehyde-3-phosphate dehydrogenase at its active site thiol by nitric oxide, peroxynitrite and related nitrosating agents. FEBS Lett. 348, 223-227.

Moncada, S., Higgs, E.A., 1991. Endogenous nitric oxide: physiology, pathology and clinical relevance. Eur. J. Clin. Invest. 21, 361-374.

Murphy, M.E., Noack, E., 1994. Nitric oxide assay using hemoglobin method. Methods Enzymol. 233, 240-250.

Packer, M.A., Miesel, R., Murphy, M.P., 1996. Exposure to the parkinsonian neurotoxin 1-methyl-4-phenylpyridinium $\left(\mathrm{MPP}^{+}\right)$and nitric oxide simultaneously causes cyclosporin A-sensitive mitochondrial calcium efflux and depolarisation. Biochem. Pharmacol. 51, 267-273.

Pfeiffer, S., Mayer, B., 1998. Lack of tyrosine nitration by peroxynitrite generated at physiological pH. J. Biol. Chem. 273, 27280-27285.

Radi, R., Beckman, J.S., Bush, K.M., Freeman, B.A., 1991. Peroxynitrite oxidation of sulphydryls. The cytotoxic potential of superoxide and nitric oxide. J. Biol. Chem. 266, 4244-4250.

Radi, R., Rodriguez, M., Castro, L., Telleri, R., 1994. Inhibition of mitochondrial transport chain by peroxynitrite. Arch. Biochem. Biophys. 308, 89-95.

Rao, D., Elguindi, S., O'Brien, P.J., 1991. Reductive metabolism of nitroprusside in rat hepatocytes and human erythrocytes. Arch. Biochem. Biophys. 286, 30-37.

Sawada, H., Shimohama, S., Kawamura, T., Akaike, A., Kitamura, Y., Taniguchi, T., Kimura, J., 1996. Mechanism of resistance to NO-induced neurotoxicity in cultured rat dopaminergic neurons. J. Neurosci. Res. 46, 509-518.

Schutte, B., Nieland, L., van Engeland, M., Henfling, M.E., Meijer, L., Ramaekers, F.C.S., 1997. The effect of the cyclin-dependent kinase inhibitor olomoucine on cell cycle kinetics. Exp. Cell. Res. 236, $4-15$.

Shi, X., Rojanasakul, Y., Gannett, Y., Liu, K., Mao, Y., Danid, L.N., Ahmed, N., Caffioti, U., 1994. Generation of thiyl and ascorbyl radicals in the reaction of peroxynitrite with thiols and ascorbate at psysiological pH. J. Inorg. Biochem. 56, 77-86.

Stadler, J., Billiar, T.R., Curran, R.D., Stuehr, D.J., Ochoa, J.B., Simmons, R.L., 1991. Effect of exogenous and endogenous nitric oxide on mitochondrial respiration of rat hepatocytes. Am. J. Physiol. 260, C910-C916.

Starke, P.E., Farber, J.L., 1985. Ferric ion superoxide ions are requried for the killing of cultured hepatocytes by hydrogen peroxide: evidence for the participation of hydroxyl radicals formed by an iron-catalyzed Haber-Weiss reaction. J. Biol. Chem. 260, 10099-10104.

Szabo, C., Salzman, A.L., 1995. Endogeneous peroxynitrite is involved in the inhibition of mitochondrial respiration in immuno-stimulated J774.2 macrophages. Biochem. Biophys. Res. Commun. 209, 739743

Troy, C.M., Derossi, D., Prochiantz, A., Greene, L.A., Shelanski, M.L., 1996. Downregulation of $\mathrm{Cu} / \mathrm{Zn}$ superoxide dismutase leads to cell death via the nitric oxide-peroxynitrite pathway. J. Neurosci. 16, 253-261.

Van Engeland, M., Ramaekers, F.C.S., Schutte, B., Reutelingsperger, 
C.P.M., 1996. A novel assay to measure loss of plasma membrane asymmetry during apoptosis of adherent cells in culture. Cytometry 24, 131-139.

Vallette, G., Jarry, A., Branka, J.-E., Laboisse, C.L., 1996. A redox-based mechanism for induction of interleukin-1 production by nitric oxide in a human colonic epithelial cell line (HT29-CI.16E). Biochem. J. 313, $35-38$.

Wang, Y., Marsden, P.A., 1995. Nitric oxide synthases: gene structure and function. Adv. Pharmacol. 34, 71-90.

Whittemore, E.R., Loo, D.T., Watt, J.A., Cotman, C.W., 1995. A detailed analysis of hydrogen peroxide-induced cell death in primary neuronal culture. Neuroscience 67, 923-932.
Wink, D.A., Hanbauer, I., Krishna, M.C., DeGraff, W., Gamson, J., 1993. Nitric oxide protects against cellular damage and cytotoxicity from reactive oxygen species. Proc. Natl. Acad. Sci. U. S. A. 90, 9813-9817.

Wiseman, H., Halliwell, B., 1996. Damage to DNA by reactive oxygen and nitrogen species: role in inflammatory disease and progression to cancer. Biochem. J. 313, 17-29.

Xie, Y.M., Wolin, M.S., 1996. Nitric oxide and its interaction with superoxide in the suppression of cardiac muscle mitochondrial respiration: implications for ischemia and reperfusion injury. Circulation 94, 2180-2186. 